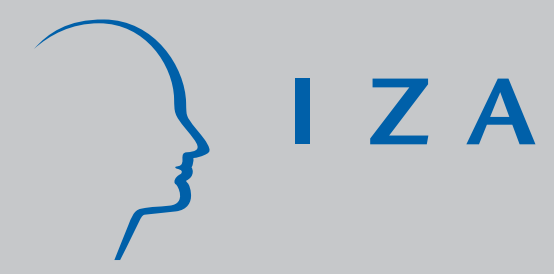

IZADP No. 1792

The Impact of Incarceration in State Prison on the Employment Prospects of Women

Rosa Cho

Robert LaLonde

October 2005 


\title{
The Impact of Incarceration in State Prison on the Employment Prospects of Women
}

\author{
Rosa Cho \\ University of Chicago \\ Robert LaLonde \\ University of Chicago, NBER \\ and IZA Bonn \\ Discussion Paper No. 1792 \\ October 2005 \\ IZA \\ P.O. Box 7240 \\ 53072 Bonn \\ Germany \\ Phone: +49-228-3894-0 \\ Fax: +49-228-3894-180 \\ Email: iza@iza.org
}

Any opinions expressed here are those of the author(s) and not those of the institute. Research disseminated by IZA may include views on policy, but the institute itself takes no institutional policy positions.

The Institute for the Study of Labor (IZA) in Bonn is a local and virtual international research center and a place of communication between science, politics and business. IZA is an independent nonprofit company supported by Deutsche Post World Net. The center is associated with the University of Bonn and offers a stimulating research environment through its research networks, research support, and visitors and doctoral programs. IZA engages in (i) original and internationally competitive research in all fields of labor economics, (ii) development of policy concepts, and (iii) dissemination of research results and concepts to the interested public.

IZA Discussion Papers often represent preliminary work and are circulated to encourage discussion. Citation of such a paper should account for its provisional character. A revised version may be available directly from the author. 


\section{ABSTRACT \\ The Impact of Incarceration in State Prison on the Employment Prospects of Women}

This paper uses a unique data set constructed from two sets of administrative records to examine the relationship between incarceration and employment rates for former female state prisoners from Illinois. Our analysis indicates that although prison is associated with declining employment rates during the quarters leading up to women's incarcerations, it does not appear to harm their employment prospects later on. In the short-term, we estimate that women's post-prison employment rates are about four percentage points above expected levels. However, these employment gains do not persist and gradually fall back to pre-prison levels. But for some groups of women, including those with four or more children, those who served longer prison spells, and those who served time for person-related or drug-related offenses, we find that modestly positive employment effects that are on the order of a few percentage points persist. These results indicate that time out of the work force or diminished skills are not costs associated with incarcerating women. Nor does a prison record appear to send an undesirable signal in the labor market that reduces former female inmates' employment chances. Although incarcerated women's subsequent employment rates are very low, they do not appear to be low because of their experience in prison.

JEL Classification: J29

Keywords: $\quad$ prison, women, employment

Corresponding author:

Robert J. LaLonde

Irving B. Harris Graduate School of Public Policy Studies

The University of Chicago

1155 East 60th Street

Chicago, IL 60637

USA

Email: r-lalonde@uchicago.edu

\footnotetext{
*We thank Steve Karr from the Illinois Department of Corrections, Grace Chan McKibben and Laura Miller from the Illinois Department of Employment Security, and Robert Goerge and Allen Hardin from Chapin Hall Center for Children for providing us with the data for this study and for many helpful discussions. We thank David Olsen and participants in the micro workshop at the University of Chicago for their comments on an earlier draft of this paper. This research has been supported by the Center for Human Potential at the Irving B. Harris Graduate School of Public Policy Studies, the Chicago Community Trust, the Russell Sage Foundation, the Open Society Institute, and the Levin Faculty Fellowship. The views expressed in this paper are those of the authors and do necessarily reflect the views of any of these organizations or the Illinois Department of Corrections and the Illinois Department of Employment Security.
} 


\section{Introduction}

The sharp rise in U.S. incarceration rates has led to increased interest in research on the labor market consequences of incarceration. Several studies have explored how prison affects male ex-offenders' subsequent chances for employment and their earnings while on the job. ${ }^{1}$ Theory suggests that incarceration could adversely affect chances for employment either because of the potential labor market experience lost while in prison, the depreciation of existing human capital, or the stigma or signal that having been in prison sends to potential employers (Freeman, 1995; 1999; Western, Kling, and Weiman, 2001). At the same time, prison, at least for some inmates, could lead to improved employment prospects if the experience improves life functioning (Western, Kling, and Weiman, 2001). To date much of the literature reports that time in prison is associated with poorer employment prospects, but one recent study by Jeffery Kling finds little evidence of adverse effects of time in prison for a sample of men from California, who had served time in federal prisons. (Kling 2002).

The literature on incarceration and its labor market consequences has focused almost entirely on men. This is expected since men account for more than 90 percent of inmates in state and federal prisons. But since 1980, the number of incarcerated females has risen by about 10 percent annually (Rafter, 1990; Beck and Karberg, 2000). On any given day, there are approximately 95,000 women serving time in state and federal prisons and roughly an equal number are incarcerated in county jails (Greenfeld and Snell, 2000; Kruttschnitt and Gartner, 2003).

This paper adds to the literature on social and economic consequences of incarceration by examining how prison affects women’s subsequent employment. Although the mounting numbers of imprisoned females motivate study of the labor market consequences of these incarcerations, they're two other reasons that we focus on women. First, the vast majority of female inmates are mothers likely to have been their children's custodial parent prior to incarceration (Mumola, 2000). Because incarceration is more likely to affect children in these cases, the social and economic consequences of

\footnotetext{
${ }^{1}$ Besides the studies cited in the text, see Freeman (1992; 1996), Grogger (1995), Nagel and Waldfogel, (1995), Needels (1996). Wadfogel, (1994a; 1994b).
} 
incarceration may differ substantially between women and men. If prison adversely affects women's employment prospects or improves them, these outcomes may have more immediate impacts on children than if they were experienced by men.

Second, women's prison spells tend be shorter and for less serious offenses than men's spells. They are more likely to serve time for drug-related offenses and are less likely to serve time for violent offenses. Given the differing circumstances that cause women to be incarcerated, there is reason to believe that prison's subsequent effects on employment might be different for them than for men.

To address the question of how prison affects women's employment prospects, we use a unique data set consisting of nearly 7,000 economically disadvantaged women who served time in Illinois state prisons, likely for the first time, between January 1, 1995 and December 31, 2000 and who had had contact with state's social or child welfare systems. We obtained records for these women from two administrative databases. First, the Illinois Department of Corrections (IDOC) provided records covering fiscal years 1990 through 2001, which contain a modest set of demographic information, detailed information on the criminal offense that lead to a women's imprisonment, and time served. Second, the Illinois Integrated Database (IDB) maintained by Chapin Hall Center for Children is comprised of individuals who have a public aid record (Food Stamps, AFDC/TANF, or Medicaid) or a child welfare record (foster care or allegation of abuse or neglect) (Goerge, Van Voorhis and Lee, 1994). For individuals with records on the IDB, we can relatively easily match this information to their Unemployment Insurance quarterly wage records starting with the first quarter of $1995 .{ }^{2}$

Our analysis of these matched data indicates that female prison inmates in Illinois are largely from an economically disadvantaged population. Further, we find, as does Kling for economically disadvantaged males, that prison is not associated with subsequently lower employment rates (Kling, 2002). ${ }^{3}$ So while women's employment rates are lower than expected while they are in prison, and decline during the quarters leading up to their incarcerations, prison does not appear to adversely affect their

\footnotetext{
${ }^{2}$ We did not have information the earnings histories of female inmates without social child welfare contacts for this paper, but such women constitute only about 18 percent of the female prison population. Presently, we are working on matching the earnings histories for this subset of female inmates and will report these findings in subsequent research.
} 
employment prospects later on. Moreover, in the short-term, during the first two full quarters after leaving prison, we find that women's employment rates are significantly above expected levels. Beyond this point these apparent gains dissipate but remain at or above expected levels in subsequent quarters.

The foregoing findings are sensitive to how much time women spent in prison and to their demographic characteristics. In general, we find that the larger positive employment effects of prison are associated with more time served in prison and not less. When we find persistent positive employment effects of prison, they are concentrated among women who are over 26 and report having 4 or more children when they enter prison. For this group, which constitutes nearly 25 percent of our sample, prison is associated with about a persistent 6-percentage point rise in employment rates. For the other women in our sample, time in prison is associated with short-term employment effects of about one-half this size, and little positive or negative impact on employment rates in the longer term. We also find that our results vary according to the type of offense that led to a woman's incarceration. Impacts on employment are substantial for women who served time for person-related and drug related offenses. By contrast, we find zero or slightly negative employment effects of prison for women who served time for property-related offenses.

The remainder of this paper discusses the sample in section II. In section III, we present our econometric framework for analyzing these data. We report our empirical results in section IV. In section $\mathrm{V}$, we discuss our results and present some concluding remarks.

\section{The Sample of Economically Disadvantaged Female Prison Inmates Constructing the Sample}

The available data in large measure dictate the composition of our sample. Our sample consists of women who entered the Illinois state prison system between January 1, 1995 and December 31, 2000 and who had not been incarcerated between July 1, 1989 and December 31, 1994. Because the literature suggests that recidivism rates are very low for individuals who have been out of prison for at least 5 years, we consider our

\footnotetext{
${ }^{3}$ Kling (2002) reports adverse affects of prison for men who served time for while collar offenses.
} 
sample to consist of women who were incarcerated in state prison for the first time between 1995 and 2000 .

The Illinois Department of Corrections (IDOC) admission and exit records contain information on the category of each female inmate's criminal offense, whether an inmate reports a substance abuse problem at the time of admission to prison, and the entry and exit dates of each prison spell. These files also include demographic information on inmates' race, birth date, schooling attainment, county from which they were committed to prison, marital status, and number of children.

To obtain the employment information used in this study, the IDOC records were matched to the Chapin Hall Center for Children's IDB database using probabilistic matching. (For details on probabilistic matching, see the appendix.) The individual records in the IDB file come from essentially two sources: the Illinois Department of Human Services (DHS) and Illinois Department of Children and Family (DCFS) services. The DHS records provide information on Food Stamp, AFDC/TANF, and Medicaid spells covering the period from 1990 through 2001. The DCFS records contain information on child welfare contacts, including foster care spells of either the women themselves or their children, dating back to 1976.

The match rate between the IDOC and IDB files was about 82 percent. The majority of these women had at least one Food Stamp spell. This high match rate between the state's prison and social and child welfare records underscores the economic disadvantage of the population of female prison inmates (Kruttschnitt and Gartner, 2003). Therefore, our study sample is well characterized as consisting of economically disadvantaged first-time female state prison inmates.

If women from the IDOC data base are found on the IDB data base, we can then obtain the quarterly wage histories as maintained by the Illinois Department of Employment Security (IDES). Those women who were not matched to the IDB data base are not part of the sample used for this study. ${ }^{4}$ This limitation has two implications for our study. First, our sample excludes inmates who did not have a social or child welfare history in Illinois between 1990 and 2001. We estimate that this amounts to about 15 to 
20 percent of inmates. Therefore, our analysis does not apply to female inmates who are not economically disadvantaged. ${ }^{5}$ Second, the measure of employment outcomes used in this study refers to jobs covered by the state unemployment insurance system.

Consequently, to the extent the women in our sample find jobs that are not covered by the unemployment insurance (UI) system, our measures of employment rates and earnings understate the incidence of employment and their earnings (Kornfield and Bloom, 1999).

\section{Characteristics of First-Time Inmates}

Our sample of first-time female prison inmates consists of 6,991 observations. We present the characteristics of these women in Table 1. As shown by the first column of the table, first-time female inmates were disproportionately black, unmarried, and high school dropouts. ${ }^{6}$ Nearly 85 percent reported having children and the average number of children among female inmates was about 2.5. Finally, these first-time prisoners were not young; they were on average about 31 years old when they entered prison.

The statistics on offense category and time-served indicate that women tend to serve short spells for non-person-related, non-violent, offenses. As shown by column 1, almost 50 percent of first-time female inmates were incarcerated for drug law violations. By contrast, only about 15 percent served time for person-related crimes. These percentages differ from those for the whole IDOC population, which is 94 percent male (IDOC 2003). The male prison population consists of substantially larger percentage of people who are incarcerated for person-related offenses.

More detailed analysis of the property-related crimes that lead to these women's incarcerations lends further support to the contention that these women tend to serve time for relatively less serious offenses than their male counterparts. The most common

\footnotetext{
${ }^{4}$ We have recently obtained Social Security numbers from IDOC officials which we are using to directly match women on the IDOC data base to the IDES data base. We will report on this matching in future research.

${ }^{5}$ We currently are working on a joint project with the Chapin Hall Center for Children, the Illinois Department of Security, and the Illinois Department of Corrections in which we use inmates' Social Security numbers as they appear in IDOC records to match prison records to quarterly employment histories. We expect this study will enable us to learn about less economically disadvantaged female offenders.

${ }^{6}$ Statistics from the 2000 Census indicate that 12.4 million people or $4.3 \%$ of the U.S. population reside in Illinois. Approximately, 42 percent of the Illinois' population resides in Cook County, which includes the
} 
property-related offense is retail theft of merchandise worth less than $\$ 150$. This offense comprises 32 percent of all women incarcerated for property-related crimes.

Perhaps because of the nature of their criminal offenses, women in our sample usually were incarcerated for a relatively short time. ${ }^{7}$ The average length of a first-time prison spell is about 0.77 years (or about 283 days). For about one-half of the sample, these spells lasted less than 6 months. Although the sampling scheme used for this study prevents women with long prison spells from appearing in our sample--especially women entering prison late in the sampling frame--relatively few women are excluded as a result. In our sample 99 percent of prison spells last less than 3.6 years. ${ }^{8}$

Another point apparent from Table 1 is that during the period studied, state prisoners reentered the labor market during relatively good economic conditions. As shown by the table, the unemployment rate in the county from which they were committed to prison averaged 4.7 percent during the quarter that they exited from IDOC custody. In our analysis below, we use this time-varying measure to capture the state of the local labor market when female reentrants searched for a job after leaving prison. But any findings we report here on the effect of prison on employment rates should be interpreted in light of these prevailing economic conditions.

Finally, Table 1 also reports the average quarterly employment rates for our sample of female offenders during the 26 quarters starting in the first quarter of 1995 . As shown in the last row of the table, these women's quarterly employment rates averaged 24 percent. As explained above, because their prison spells tend to be short, time spent in prison can not explain why their employment rates are low. These low employment rates reinforce the point, apparent from the other demographic characteristics in the table, that female offenders with social or child welfare contacts--the vast majority of all female offenders in the state--constitute an economically disadvantaged population.

city of Chicago. Nearly, 14 percent of the state's 18 and older population is black, and 81 percent of the 25 and older population is a high school graduate. See www.factfinder.census.gov.

${ }^{7}$ Time served should not be confused with the length of a women's sentence. Because statutory and discretionary good time credits, actual time served is almost always less than one-half the length of the original sentence.

${ }^{8}$ Further as shown in Table 1, the average length of prison spells for women who entered early in the sample period, in 1995 or 1996, and who we can follow for up to five years, is still under one year. Consequently, when we discuss below how our results differ between women who completed very short as opposed to longer prison spells, the longer prison spells we refer to are still relatively short, lasting between 6 months and 3.6 years. 
Although our sample of first-time female inmates is drawn from an economically disadvantaged population, the employment rates reported here do not indicate that they are especially disadvantaged compared to women that have been served by state social welfare agencies over time. Their employment rates, while low, are comparable to those reported from the same kind of administrative data for participants in the WIN Demonstration Work-Welfare and the JOBS evaluations of the 1980s and 1990s. ${ }^{9}$ In some of those evaluations, participants' quarterly employment rates averaged as little as 10 percent, while in other evaluations they averaged nearly 35 percent. $^{10}$

\section{Quarterly Employment Rates and Time since Entry to Prison}

To begin our study of the relationship between incarceration and employment, we present the temporal pattern of the relationship between these women's quarterly employment rates and time since prison entry or exit. To construct these statistics, we computed for each person/quarter observation the number of quarters between the current quarter and the quarter a woman entered prison or the number of quarters between the current quarter and the quarter she exited from prison (or left IDOC custody). We call this variable "relative quarters." Then for each relative quarter, we computed the average quarterly employment rate for the sample. We present these employment rates by relative quarter in Figure 1.

As shown by Figure 1, two to four years prior to entering prison, women's quarterly employment rates averaged about 25 percent. During the second year prior to the quarter that they entered prison for the first time, their employment rates started to decline. By the quarter prior to the quarter that they entered prison, their employment rates were below 20 percent. During the quarter they entered prison their employment rates are even lower, but they were not equal to zero. We do not expect quarterly

\footnotetext{
${ }^{9}$ In these evaluations, officials welfare applicants and recipients were randomly assigned to receive various employment and training and educational services or to a control group. As shown by Table A, the employment rates that we report for female inmates with social welfare histories lies in the middle of the range of average employment rates reported for the WIN Demonstration Work-Welfare and the JOBS control groups.

${ }^{10}$ Kling (2002) reports that quarterly employment rates for his sample of male inmates from California averaged about 35 percent. Given the labor market performance of men generally exceeds that of women, even in the economically disadvantaged population, we expect that the average employment rates of female inmates to be less than those of comparable male inmates.
} 
employment rates to equal zero during the quarter women enter prison, because it is still possible to have a job and enter prison during the same quarter.

After women leave prison their employment rates are greater than they were during the pre-prison period. During the quarter that they exited from prison their employment rates were near their highest pre-prison levels and then they rise to over 30 percent during the quarters immediately after the quarter that they exited from prison. The level of employment during this period suggests about a 5-percentage point impact on employment in the immediate post-prison period. Afterwards, these women's quarterly employment rates decline somewhat, but even after 20 quarters they remain a couple of percentage points above their pre-prison levels.

The pattern of employment rates presented in Figure 1 suggests that time in prison does not adversely affect women's employment rates. Indeed, the pattern depicted in the figure suggests that prison may actually be associated with modestly improved employment prospects, at least in the short-term. There are many reasons why this pattern might not reflect any causal relationship between prison and employment. Indeed, our econometric model and associated empirical work developed below attempt to address such concerns. But even after we consider several different approaches to estimating the impact of prison on employment, we find that the temporal pattern in Figure 1 continues to convey the key relationships in the data.

\section{Quarterly Earnings when Employed}

For our sample of first-time inmates, we focus our analysis on employment rates and not earnings because we were not provided information on quarterly earnings. Instead, we have total earnings during each spell of employment (covered by the UI system) during the period covered by our study. To present this information in a way that conveys female ex-offender's earnings potential when they work, we computed the average quarterly earnings during quarters in which women were employed. (See Appendix for details on how we constructed this variable.)

We find that for female inmates in our sample employment is associated usually with very low earnings. As shown by Table 2, we estimate that when female inmates worked they earned on average about $\$ 1,845$ per quarter. Their median quarterly earnings 
were $\$ 1,174$. This median earnings figure is consistent with a woman working about 18 hours per week at the federal minimum wage. Therefore, in this sample being employed does not mean that a woman is likely self-sufficient and free of the social welfare system.

\section{Earnings Potential and Poverty}

To examine this point further, we used our calculations of average quarterly earnings and the number of children to estimate how many women when they worked had likely ever earned enough during a given quarter to ensure that her family income was above the poverty threshold. ${ }^{11}$ Our calculations indicate that during the $61 / 2$ year period covered by our sample only about 10 percent of the women ever held a UIcovered job in which their average earnings were sufficient to ensure that their household income was above official poverty thresholds for at least one quarter. To be sure, because our sample is limited to women with social welfare histories, we expect this percentage to be low. ${ }^{12}$ But since most female inmates have such histories, this percentage indicates that this population, at least in Illinois, lives in persistent poverty. The foregoing calculation likely underestimates somewhat the potential for these women to live above the poverty threshold during the sample period, because we are not accounting for the income of a married woman's spouse. To account for this possibility, we re-estimated the percentage of women out-of-poverty by assuming all married inmates would reside in households with incomes above the poverty threshold. In this case, we estimate that during the sample period perhaps as many as 21 percent of the women lived in a household that was out of poverty for at least one quarter. We regard this figure to be the upper bound for the percentage of these women who were ever outof-poverty during the sample period, since it is likely that incomes in some of these households with married partners would never have reached the poverty threshold.

\footnotetext{
${ }^{11}$ We assume that each woman is the household head. As shown by Table 1 only 12 percent of the female inmates reported being married. Accordingly, in our poverty calculations, we assume that if a woman was married her spouse's earnings were negligible.

${ }^{12}$ According to the U.S. Census Bureau the poverty rate in 2000 for female headed families with no workers was nearly 70 percent. The poverty rate among such families with at lest one worker was 21 percent (Dalaker 2001).
} 


\section{A Statistical Model of the Impact of Prison on Employment Rates}

To estimate how prison affects employment rates, we use three different approaches. First, we use the pre-prison employment rates of women who enter prison later in the sample period as a comparison group for women who entered early in the sample period (Kling 2002). Second, we compare employment outcomes between women who served longer prison spells and women who served shorter spells. The literature is unclear about the direction of the effect of time served in prison on employment prospects. The assumption underlying this alternative estimation approach is that if prison impairs (improves) a woman's labor market prospects, then more time spent in prison should be systematically associated with lower (higher) employment rates. Finally, we identify the employment effects of prison from the difference between each woman's post- and pre-prison employment rates. This fixed-effects estimator is identified because women enter prison at different times during the sample period.

Each of the foregoing approaches has advantages and disadvantages. The advantage of our first approach is that our comparison group consists of women who are similarly selected from the population of economically disadvantaged women.

Alternatively, had we used as our comparison group, women who had never been incarcerated, we would also have to model the processes that cause some women in the population be incarcerated.

A disadvantage of our first approach is that the factors that influence individuals' entry into prison may vary over time. When studying incarcerated women changing economic, social, and policy variables may make later (first-time) prison-entry cohorts different from early first-time prison cohorts. ${ }^{13}$ We observed this possibility when we compared the demographic characteristics of these early and late cohorts in Table 1. Therefore, we address this problem to some extent in our empirical work by controlling for differences among female inmates’ observed characteristics and for changes in county unemployment rates.

The advantage of our second approach is that we compare women who enter prison at the same time and identify the effect of incarceration from variation in time

\footnotetext{
13 The analogy to the employment and training setting is the composition of successive training cohorts change over time (Ashenfelter, 1978).
} 
served. To be sure, differences in time served among those who enter prison at the same time may be associated with different policy and economic environments upon release. We believe that we mitigate their importance on our results by including controls for time and region effects and time-varying local unemployment rates. The disadvantage of this approach is that variation in time served may be correlated with unobserved characteristics that influence labor market success. We believe that even after holding constant women's observed characteristics, those who serve longer have unobserved characteristics that most likely are associated with poorer not better employment prospects. If this is the case, the results reported in the next section would tend to understate any positive effect that prison has on employment rates. But any negative effects of prison on employment could be spurious.

Finally, in our third approach our comparison group consists of each woman's pre-prison employment history. This differencing strategy purges correlation between the timing of a women's entry into prison and unobserved characteristics that are associated with her chances of being employed. The disadvantage of this approach is that because every woman in the sample spends time in prison at some point during the sample period, to identify the model, we must impose additional restrictions either on the post-prison employment effects or on the time effects. We believe these restrictions, described below, are consistent with the data.

To implement these three approaches, we estimate models of the following form:

$$
\mathrm{Y}_{\mathrm{it}}=\mathrm{B} \mathbf{X}_{\mathrm{it}}+\delta\left(\tau ; \mathrm{S}_{\mathrm{i}}, \mathbf{Z}_{\mathrm{i}}\right) \mathrm{f}_{\mathrm{i}}\left(\mathrm{t} ; \mathrm{S}_{\mathrm{i}}, \mathbf{Z}_{\mathrm{i}}\right)+\gamma_{\mathrm{t}}+\varepsilon_{\mathrm{it}}
$$

In (1), we define $\mathrm{Y}_{\text {it }}$ as a dummy variable indicating whether a woman had any UIcovered earnings during the (calendar) quarter t. The variable $\mathbf{X}_{\mathrm{it}}$ denotes a vector of observed characteristics described above in the text. The only two time-varying variables in $\mathbf{X}_{\mathrm{it}}$ are a woman's age and the unemployment rate in the county from which she was sent to prison. The term $\gamma_{\mathrm{t}}$ denotes time-effects that account for the effect of changing statewide economic conditions and policies on the employment prospects of female 
inmates. ${ }^{14}$ The term $\varepsilon_{\text {it }}$ denotes unobserved characteristics. When we allow for an individual "fixed effect" in our analysis, we define the term $\varepsilon_{i t}$ as follows: $\varepsilon_{i t}=b_{i}+v_{i t}$. Otherwise, we assume that the time-varying component of the error is independently distributed. Our standard error estimates are "robust standard errors" that take account that the unobservable characteristics in our model are not identically distributed across individuals and time periods.

In (1), the term $\delta\left(\tau ; \mathrm{S}_{\mathrm{i}}, \mathbf{Z}_{\mathrm{i}}\right)$ denotes the effect of prison on employment and the term $\mathrm{f}_{\mathrm{i}}\left(\mathrm{t}, \tau ; \mathrm{S}_{\mathrm{i}}, \mathbf{Z}_{\mathrm{i}}\right)$ denotes the relative quarter prior to, during, or since prison at time $\mathrm{t}$. We define the term $\tau$ as the relative quarter or number of quarters between the current quarter and the quarter that a woman enters or exits prison. We allow the effect of prison, $\delta\left(\tau ; \mathrm{S}_{\mathrm{i}}, \mathrm{Z}_{\mathrm{i}}\right)$, to vary according to the number of quarters between the current quarter and the entry and exit quarters from prison. We assume, however, that these prison effects are time invariant. This restriction means that we assume that the effect of prison among early admission cohorts is the same as the effect of prison for later admission cohorts.

In our empirical work below, we explicitly examine the relationship between prison and employment rates during the period prior to entering prison. After some analysis of the data, we found that our post-prison results are sensitive to whether we control for prison-effects up to 6 quarters prior to the quarter that a woman enters prison. Knowing whether the current quarter was 7 or more quarters prior to the start of a prison spell does not predict post-prison employment rates. In terms of the notation above, we set $\delta\left(-7 ; \mathrm{S}_{\mathrm{i}}, \mathbf{Z}_{\mathrm{i}}\right)=\delta\left(-8 ; \mathrm{S}_{\mathrm{i}}, \mathbf{Z}_{\mathrm{i}}\right)=\ldots=0$. This restriction is sufficient to identify the prison effects that we report in the paper.

We specified the effect of prison on employment rates in two different ways: First, we allow for separate effects of prison in each of 6 pre-prison quarters and the quarters women are in prison, and each of the post-prison quarters. Analysis of the results from this very flexible specification suggested a more parsimonious model. In our second specification we constrained the effects of prison to be the same during pre-prison

\footnotetext{
${ }^{14}$ In our empirical work we control for these effects by including a vector of 24 dummy variables indicating the time period of the current quarter. These effects also control for seasonal effects in the data. Women in this sample were least likely to be employed during the first quarter of the year.
} 
quarters 5 and 6, 3 and 4, 1 and 2, respectively and during quarters in which a woman is in prison. We also allow prison to have separate employment effects during the quarters that women enter and exit prison; and to have the same effect during each post-prison quarter. Finally, we specify a slightly less restricted version of the second model in which we allow for separate effects of prison during the first and second full quarters after a woman leaves prison. In this third model, we constrain the effect of prison to be the same during all quarters starting in the third quarter after the quarter a woman exits prison.

The terms $S_{i}$ and $\mathbf{Z}_{\mathrm{i}}$ in $\delta\left(\tau ; \mathrm{S}_{\mathrm{i}}, \mathbf{Z}_{\mathrm{i}}\right)$ denote the time served (in years) during the first prison spell, and a vector of characteristics to allow for heterogeneity in the effects of prison across individuals, respectively. In our empirical work, we add to our specification of the prison effects an interaction term, which is the product of an indicator variable indicating whether the current period is after the quarter that a woman exits from prison and the amount of time served in prison. In this approach the coefficient associated with this interaction term gives the effect of a one-year increase in time served in prison on post-prison employment rates.

A potential shortcoming of our specification (1) is that we assume that there is no state dependence in the relationship between employment rates across quarters. ${ }^{15}$ In the following section, we present evidence that this is not a reasonable assumption. Women who are employed in any given quarter are much more likely to be employed during the following quarter than are women who are not employed during the same quarter. Such evidence suggests we should consider controlling for employment status during the prior quarter, $\mathrm{Y}_{\mathrm{it}-1}$, in addition to the variables that we include above in (1). However, as we explain below, it is likely that such state dependence causes us to understate any inferences about the long-term positive employment effects of prison based on effects we estimate during the first few post-prison quarters. Indeed, in the presence of state dependence, the effects of incarceration should vary with time as women become reemployed after exiting prison.

State dependence arises because of differences between the retention and accession rates from employment. But does prison affect these transition rates?

\footnotetext{
${ }^{15}$ An analogous issue arises in program evaluations in the employment and training literature (Card and Sullivan, 1988).
} 
After we examine the effects of prison on employment, we then examine the relationship between prison and women's quarterly transition rates from employment and from nonemployment. To estimate these relationships, we specify the transition rate $\lambda_{j}(t)$ from an employment spell $(\mathrm{j}=1)$ or from a non-employment spell $(\mathrm{j}=2)$ as follows:

$$
\lambda_{j, q}(t)=1 /\left(1+\exp \left(\delta_{j}(\tau)+B_{j} X_{i, t}+h_{j, q}(q)+\gamma_{t}+\Phi_{j}\right)\right), \text { for } j=1,2 \text {. }
$$

In (2), the transition or hazard rate out of a spell type $\mathrm{j}$ during quarter $\mathrm{q}$, which is $\mathrm{q}$ quarters since the start of the spell, is given by a logit function of the vector of prison effects, $\delta_{j}(\tau)$, individual and labor market characteristics $X_{\mathrm{i}, \mathrm{t}}$ time in the spell, $\mathrm{h}_{\mathrm{j}, \mathrm{q}}(\mathrm{q})$, and the current calendar quarter. Among the characteristics we control for, only age and local unemployment rate are time-varying. We model prior time in spell $j$ at time $t$, or the duration dependence, as $g_{1} \log (q)+g_{2}(\log (q))^{2}$. The term $\Phi_{j}$ captures the effects of any unobserved heterogeneity in characteristics among women. In this paper, we ignore how this heterogeneity may affect our estimates of the prison effect and treat these terms as constants for each type of spell. ${ }^{16}$

We model the prison effects, $\delta_{\mathrm{j}}(\tau)$, in the same way that we modeled them above in (1). We allow prison to affect transition rates during the 6 quarters prior to entering prison, and during the quarters that women enter and exit prison. We also allow prison to have separate effects on transition rates during the first two full quarters after leaving prison and restrict the prison effect on transition rates to be the same way during all subsequent quarters starting with the third full quarter after release.

From our analysis of these transition rates, we better understand the likely way prison affects employment rates. If prison reduces (raises) employment rates, we should be able to determine whether this result occurs because after prison a woman's probability of leaving a non-employment spell falls (rises), her probability of leaving an

\footnotetext{
${ }^{16}$ We also include left-censored employment and non-employment spells in the analysis. In the presence of duration dependence the transition rates from these spells will differ from the transition rates from spells that began after the start of the sampling frame. In the case of transition rates from employment spells, we believe it likely that including these left-censored spells will cause us to overstate the effect of prison on the transition rates out of employment spells. The opposite is likely true for non-employment spells (Ham and LaLonde, 1996).
} 
employment spells rises (falls), or because it is a combination of these effects on her transition rates.

\section{Estimates of the Effect of Incarceration on Employment Rates}

\section{Relationship between Other Variables and Employment Rates}

We present the basic results of our analysis in Table 3 and in Appendix Table B. Before discussing our estimates of the prison effects in Table 3, we examine the estimated coefficients associated with the other variables in our model, which we present in Appendix Table B. These results reveal significant differences in the labor market prospects of different groups of incarcerated women. Being black, being from Cook County, being a high school dropout, being older, and having a large number of children are all associated with a lower probability of being employed. The -0.056 coefficient associated with being black indicates that after holding constant all the variables indicated in the table, the likelihood of observing a black woman employed either before or after prison is about 5.6 percentage points lower than it is for an observationally similar non-black woman. ${ }^{17}$

The table also reveals that employment rates for female inmates from Cook County are generally lower than they are for observationally similar women from other parts of the state, including from the (suburban) collar counties surrounding Chicago. ${ }^{18}$ During the period studied here, women who were incarcerated from Cook County had employment rates that were on average 13 percentage points lower than the rates for women from the state's rural counties. ${ }^{19}$ Apparently the employment prospects of women

\footnotetext{
${ }^{17}$ Since the average quarterly employment rate during the period studied is about 24.4 percent, this coefficient in the table suggests that in this population of incarcerated women, black female inmates were about 23 percent (i.e. $0.056 / 0.24 * 100 \%$ ) less likely to be employed in any given quarter.

${ }^{18}$ A similar result is observed among men released from IDOC's Sheridan facility. This facility provides a range of drug treatment and reentry services to male inmates with substance abuse problems. (Personal communication with David Olsen, Loyola University, Chicago and the Illinois Criminal Justice Information Authority.)

${ }^{19}$ When we explored (in work not shown in the table) whether this result reflected the different racial/ethnic composition of women from Cook County as compared to elsewhere in the state, we found this result held for both blacks and non-blacks. We also could not find any evidence that this result arose because women from Cook County had served more time in prison for their offenses and thus lost more potential time in the labor market.
} 
likely to be incarcerated in state prison are especially poor among women from Cook County. ${ }^{20}$

The results in the table also suggest that the relationship between having children and the probability of being employed is non-linear. Women with zero, one, or two children had similar employment rates throughout the period studied, with the rate for women with one child the highest. But beyond this point, the likelihood of being employed drops modestly with the number of children. The coefficients in the table suggest that the probability that a woman with 8 children being employed during any given quarter during is about 9 percentage points less than that for observationally similar women with just one child.

The coefficients associated with the type of offense that lead to a woman's imprisonment indicates little relation between these variables and employment rates, except for the variable indicating sex-related offenses. These women's quarterly employment rates were about 10 percentage points lower (or about 33 percent less) than those for other women. Although this group constitutes only a small percentage of the women in our sample (see Table 1), because their employment chances were so consistently different from the other women we examined whether our results changed when we excluded this group from our analysis. In no case did our results change, so we have continued to include these women in the analysis that follows.

Finally, we observe that the employment rates of female offenders are sensitive to local labor market conditions as captured by their county unemployment rate. The coefficient of - 0.016 suggests that a one percentage point increase in the local unemployment rate above the regional average during the sample period is associated with about a 1.6 percentage drop in the probability of being employed in any given quarter. $^{21}$ If we consider a four-percentage point change in unemployment rates--the difference between a strong and weak labor market--we estimate that this change would be associated with about a 6.5 percentage point decline in the probability of being

\footnotetext{
${ }^{20}$ Using the IDB data base, Lee, Goerge, and Dilts (1999) report lower quarterly employment rates during approximately the same period for Cook Country women who left AFDC/TANF compared to their counterparts from other Illinois counties.

${ }^{21}$ Our statistical model includes controls for Cook County, the surrounding counties, known as the collar counties, whether the county includes an MSA other than Chicago, and whether the county is a rural
} 
employed or about 25 percent of the mean employment rate. Because of this finding, we explore below whether the magnitude of the effects of incarceration is sensitive to prevailing labor market conditions.

\section{Incarceration and Pre-Prison Employment Rates}

We now turn to the effects of prison on the probability of being employed. The pattern shown in Table 3 indicates that during the 6 quarters prior to entering prison, women's employment rates are below their expected levels and declining as they approach the quarter that they enter prison. This pattern is often reported in studies of participation in means-tested social programs (Heckman, LaLonde, and Smith, 1999).

For the women studied here, there are at least two reasons why we expect to observe this pattern of declining pre-prison employment rates. First, prior to going to prison most of these women are likely incarcerated at least briefly in the jails located in the counties in which they have been charged with a crime. The reason why employment rates are declining during the period leading up to prison is that an increasing percentage of these women are incarcerated in county jails the closer the current quarter is to the date of their admission to prison. In future research we will explore the importance of this possibility using a sample of women from Cook County for whom we have detailed admissions and exit data for both prison and jail.

A second reason that we expect employment rates to decline as the quarter women enter prison approaches is that the circumstances that may make women more likely to enter prison in any given quarter also may make them less likely to be employed. Given that these circumstances are likely to be correlated across quarters, we would expect relative employment rates to decline the closer a woman is to the quarter that she enters prison.

Turning next to the period when women are in prison, we find as expected that women's employment rates fall sharply when they enter prison. It is still possible to be employed during the quarter that a women enters prison, especially if a woman entered prison relatively late during the calendar quarter. Likewise, it is possible to be employed

county. Therefore, our measure of local unemployment rate should be interpreted as the deviation of the county unemployment rate from the mean unemployment within each of these regions. 
while in prison, because prior to leaving the prison system, women are sometimes moved to an Adult Transition Center in which they hold regular jobs covered by the state's unemployment insurance system while still in IDOC custody.

\section{The Effect of Incarceration on Post-Prison Employment Rates}

After we adjust for the variables listed in Table 3, we still find, as we did in Figure 1, that the female inmates' employment rates are at their highest levels immediately after they exit prison. According to column 1 of Table 3 , during the quarter that women leave prison, their employment rates are only 1 percentage point less than expected based on their pre-prison employment rates and on the employment rates of other women who will enter prison for the first time in the future. During the remaining post-prison period, their employment rates are on average about 2 percentage points above their expected levels. Thus, prison does not appear to adversely affect these women’s employment prospects.

The evidence in Figure 1 suggested that positive post-prison effects on employment dissipate with time since exit. In column 2 of the table, we allow the postprison effects to vary during the first two full quarters out of prison. During the first full quarter out of prison, women's employment rates average 5 to 6 percentage points above their expected levels. This impact declines in subsequent quarters. During the second full quarter out of prison, employment rates average 2 to 3 points above their expected levels. And during the remaining post-prison quarters, women's employment rates are on average equal to expected levels. In other words, during our sample period, women were most likely to be employed during the first two full (calendar) quarters after their release from prison. This result holds after controlling for a broad set of characteristics, including the category of offense that lead to a women's incarceration and local labor market conditions. Therefore, not only does prison not harm Illinois women's employment prospects, but in the short-term it is associated with modestly improved chances of employment. During the six-month period after they exit prison for the first time, women's employment rates are about 10 to 20 percent above expected levels.

The evidence presented in Figure 1 and in column 2 indicates that the short-term positive effect of prison on employment dissipates during subsequent quarters. To 
explore this pattern and to see whether these women's employment rates return to their expected levels or eventually fall below them, we re-estimated our model and allowed the effects of prison to take on different values for each post-prison quarter. In Figure 2 we present these estimated impacts by quarter since entry and exit from prison along with the 95\% confidence interval associated with each estimate. With such a large number of additional parameters in the model (20), our estimates become very imprecise. Nonetheless, the resulting pattern is consistent with the estimates reported in Table 3. In the short-term, prison is associated with a positive impact on employment, but over the long-term, it appears to have neither a positive nor negative impact on employment rates.

\section{Identifying Prison Effects from Time Served In Prison}

We indicated above that an alternative way to estimate the impact of prison on employment is to compare employment rates among women who served more time in prison to observationally similar women who served less time. If prison really improves women's short-term employment prospects, we expect these effects should be larger for women who spent more time in prison compared to women whose time served was relatively brief.

To explore further the relationship between time served and employment outcomes, we re-estimated our statistical model in two ways: First, we included in our model the interaction of a dummy variable indicating whether the current quarter is a post-prison quarter and a women's time served in years. These results we report in columns 3 and 4 of Table 3. In our second approach to examining the relationship between time-served and the employment effects of prison, we divided our sample into two groups: Women who served less than 6 months in prison, and women who served 6 or more months in prison. We report these results in columns 5 and 6 of Table 3.

Examining the results in columns 3 through 6 of the table, we observe that controls for time served in prison have a substantial impact on our results. Longer prison spells are associated with improved employment prospects even beyond the short-term. As shown by column 3, the (point) estimates of the post-prison variables are now negative. But the interaction term is positive and relatively large at 6 percentage points. These estimates imply that for women who serve very short spells, say two months, 
prison probably is associated with a slightly lower chance of being employed. By contrast, during the period beyond the second full quarter after exiting prison the employment rates of former inmate's who served one year in prison average about to 4 (or $6.3+-2.1$ ) percentage points above expected levels. ${ }^{22}$

The foregoing relationship between the prison effects and time served also is seen in our results in columns 5 and 6 of the table. As shown by column 5 , the post-prison employment rates of women who served less than 6 months in prison are unaffected by prison. This result is consistent with the idea that these women's prison spells were too short to lose much labor market experience or to acquire the services offered in prison that might improve life functioning or health.

By contrast, the post-prison employment rates of women who served 6 months or more are significantly above their expected levels. As shown by column 6 of the table, during the first two quarters after the quarter they exit prison, these women's employment rates average 7 to 10 percentage points above expected levels. Although these effects decline, beyond the second full quarter after exiting prison, these women's employment rates still average 3 to 4 percentage points above expected levels. Further, these estimates are consistent with the results presented in column 3 that suggested one year in prison raises employment rates by about 6 percentage points. Interestingly, if these estimates reflect a causal relationship between time-served and increased employment rates, they are comparable in magnitude--though at a very high cost--to those reported for employment and training programs targeted toward economically disadvantaged women (Heckman, LaLonde, and Smith, 1999).

\section{Examining the Sensitivity of the Estimates to Changes in the Statistical Model}

We also explored the sensitivity of our results to alternative specifications of our underlying statistical model. First, we examined how sensitive our results were to our controls for demographic characteristics and type of offense. We found that excluding these variables lead us to estimate smaller positive effects of prison on subsequent employment rates. This result suggests that the early entrants into prison during our

\footnotetext{
${ }^{22}$ In column 4, we observe that this finding is unchanged after we account for the possibility that the postprison effects are sensitive to differing prevailing labor market conditions.
} 
sample period have characteristics that make them less employable than the later prison entrants. These results also raise the possibility that our analysis may omit important unobserved and unmeasured personal characteristics that influence the results we report in Table 3. We address this possibility below with our fixed effect estimates.

Next, we examined the sensitivity of our results to the pre-prison variables that we included in our model. Without these variables, our estimated impacts of prison rise by about 2 to 3 percentage points relative to the estimates reported in column 2 of the table. As indicated above, without our pre-prison variables we tend to underestimate women's pre-prison employment prospects, which in turn causes use to overestimate the impact of prison on post-prison employment rates.

\section{Fixed-Effect Estimates}

To address the possibility that failure to control for unobserved and unmeasured (fixed) characteristics may bias our results, we estimate the fixed-effect version of our statistical model described in section III. It relies on the assumption that holding constant local labor market conditions and current age, differences between women's post- and pre-prison employment rates reflect the impact of prison. ${ }^{23}$ This model is identified because women enter and exit prison during different quarters in the $61 \frac{1}{2}$ year sampling period.

As shown by Table 4, the point estimates of the post-prison effects from the fixed-effects version of our model are smaller and closer to zero. But overall our findings are similar to those reported in Table 3. Over the longer term, the (point) estimate in column 1 suggests that, on average, time served in prison has no effect one way or the other on women's employment rates. But as indicated by the size of the standard errors associated with these estimates, the estimates we report are consistent with those produced in column 2 of Table 3.

In column 2 of Table 4, we observe that relatively longer prison spells are again associated with increased post-prison employment rates. The impact of one year in prison is about a four-percentage point increase in employment rates during the post- 
prison period. This impact is similar to but somewhat smaller than the comparable estimate that we report in column 3 of Table 3 . We also find that prison improves employment prospects for those women who served more than 6 months and appears to have no effect one way or the other on the employment rates of women who served less time.

\section{Employment Accession and Retention Rates}

As we discussed in section III, our statistical model is misspecified if employment rates are subject to "state dependence". As shown by the figures in Table 5, a woman who is employed in any given quarter is more likely to be employed during the following quarter than a woman who is not employed during that quarter. We find that 6.7 percent of non-employment spells ended during any given quarter, whereas 75.2 percent (10.245) of employment spells continue as employment spells the following quarter. This means that for women in our sample employment retention rate is higher than the accession rate. These facts indicate that prior employment status predict current employment status.

Implicitly in model (1), we assume that once we control for all the characteristics in the vector $\mathbf{X}_{\mathrm{it}}$, knowing whether a woman is employed during the prior quarter does not predict whether she is employed in the current quarter. In addition, in the fixed effect estimation of model (1), we assume that previous employment should not predict current employment once we control for observed characteristics in vector $\mathbf{X}_{\mathrm{it}}$ and any fixed unobserved characteristics. Thus, estimates reported in Table 5 imply state dependence if the difference in retention and accession rates cannot be fully explained by differences in women's observed characteristics and other unobserved characteristics such as innate ability or motivation. In this case, our estimates in Table 3 and 4 will be biased.

Despite this evidence of state dependence, we believe its presence most likely causes us to understate the positive effects that prison seems to have on employment rates. Suppose the circumstances that cause women to enter prison and cause their employment rates to decline during the 18 months leading up to prison are correlated

\footnotetext{
${ }^{23}$ We also control for whether a woman was sentenced from Cook County, from one of the "collar counties” surrounding Cook County, from a county containing a smaller MSA (such as Rockford, Peoria,
} 
across time periods. Then during the post-prison period, employment rates will tend to be below normal expected levels, even if prison has no effect one way or the other on employment rates. Because our econometric specification implies that we compare women's post-prison employment rates to their employment rates more than 18 months prior to entering prison, our estimates indicating that prison improves short-run employment prospects are likely downward biased. This means that using the short-run effects to extrapolate long-run effects would likely cause us to understate the effects of prison.

These transition rates also provide some explanation as to why we observe increased employment rates during the immediate post-prison period. Comparing columns 2 and 3 of Table 5, we observe that the transition rates out of employment are lower after prison than they were before prison. It also is the case that transition rates out of non-employment are a little higher during the post-prison periods. Together these two facts account for the higher post-prison employment rates.

To explore further this issue and how it might affect our results, we computed the transition rates from non-employment to employment and employment to nonemployment for each female inmate. We estimated the relationship between the quarterly transition rates shown in Table 5 and the set of characteristics used in our analysis of the employment effect of prison using model (2). ${ }^{24}$ We summarize our results in Table 6 , and present a complete set of estimates in Appendix Table C. As shown by the first two columns of the table, after holding constant the indicated demographic variables, we find that the reason for the lower post-prison transition rates out of employment is consistently lower employment transition rates throughout the post-prison period. This conclusion also holds for employment held during the quarter that women were released from prison.

By contrast, as shown by the last two columns of the table, we find that while women are more likely to exit non-employment after prison, this result occurs because of

or Decatur), or from a county from the rural part of the state.

${ }^{24}$ We assumed the transition rate in any relative quarter is given by (2) in the text (Ham and LaLonde, 1996). In this analysis of transition rates, we ignore the complications associated with left-censoring, and unobserved heterogeneity. (Cf. Heckman and Singer 1984). Given that we include left-censored employment spells in the analysis, we believe that the employment transition effects are likely understated 
relatively high transition rates during the quarter women exit from prison and during their first full quarter after prison. But beyond this quarter, non-employment transitions are the same or lower than expected. Taken together, these results suggest that increased employment retention rates are an important part of the explanation for the increased employment rates we observe following a prison spell. But eventually as women fall out of employment their chances of becoming employed again maybe no larger and may even be a little less than they were during the pre-prison period.

\section{Heterogeneity in the Impact of Prison on Employment}

As discussed above, female prisoners differ in at least two important ways from their male counterparts: First they are likely to have been custodial parents. Second, they serve time for less serious offenses. In this subsection, we examine how these two characteristics of female inmates influence our results on the employment impact of prison.

\section{Employment Effects by Number of Children}

We observed above in connection with our discussion of Table 3 that having many children is associated with a lower probability of employment. To explore whether having children affects the employment impact of prison, we estimated our statistical model separately for different groups of women depending on the number of children they reported when they entered prison. Inspecting these results we found it instructive to consider separately the results for women with 0 children, 1 to 3 children, and 4 or more children.

As shown by columns 1 and 3 of Table 7, the post-prison employment rates of women with no children or 1 to 3 children are about 4 to 6 percentage points above expected levels during the first two full quarters after leaving prison. Then beyond this point, our estimated prison effects are close to and not statistically significantly different from zero.

(in absolute value). This occurs because the pre-prison period includes some employment spells in which the observed transition rate likely understates the transition rate from a typical (fresh) employment spell. 
By contrast to the results for women with few or no children, women with 4 or more children experienced much larger and more persistent employment rate increases associated with their prison experience. As shown by column 5, during the first full quarter after leaving prison, their employment rates were about 8 percentage points above expected levels. Given this group of women’s employment rates average only 19.5 percent during the sample period, this impact in percentage terms is about 39 percent. This prison effect declines somewhat during subsequent quarters, but after leaving prison, these women's employment rates remained about 6 percentage points more than what we would have expected. Given that we hold constant a woman's current age, having many children is likely a signal of economic disadvantage. ${ }^{25}$ These results suggest that the positive employment effects we observe in this paper may be concentrated among the more disadvantaged women in our sample. ${ }^{26}$

The results in the even columns of Table 7 emphasize differences in prison effects by time served for the three groups of women. For all three groups of women, estimates for post-prison variables indicate that very short prison spells are associated with the same or lower employment rates. But the interaction term indicates that more time in prison is associated with increased post-prison employment rates. For both groups of women with children, one year in prison is associated with about a 7 percentage point increase in employment rates. For the women without children, the effect is less than one-half this size.

The results above indicate that the prison effects we observe are strongest with women who report having many children. We explored this further and found that the largest positive employment effects of prison were for women 26 or older with four or more children. Beyond the second full month after leaving prison, these women's

\footnotetext{
${ }^{25}$ Comparing the characteristics of women with four or more children to women with less than four children, we find that women in the former group are more likely to be black (by 19 percentage points), to be a high school dropout (by 10 percentage points, and to have served time for a drug-related crime (by 10 percentage points). On average the employment rates during the sample period for this group are about 7 percentage points less than other women. Average durations of prison spells are nearly the same for both groups.

${ }^{26}$ To explore this possibility further, we also examined whether our results depended on a woman's schooling. Presumably women who were high school dropouts are more economically disadvantaged than their counterparts with a high school degree. However, we found no significant difference between the post-prison employment effects for women who were high school dropouts and women who were high school graduates.
} 
employment rates averaged 5 percentage points above expected levels. For all other women in the sample employment rates were at their expected levels after the second full quarter after exiting prison.

\section{Employment Effects by Category of Criminal Offense}

We also analyzed our sample separately by category of criminal offense to see whether the employment effects we documented above varied by a woman's offense category. ${ }^{27}$ The evidence presented in Table 8 indicates that employment effects are larger for women who served time for person-related offenses and smallest for women who served time for property-related offenses. Significantly, the former category of women tended to serve the longest prison spells and the later category of women tended to serve the shortest spells.

As shown by the results in Table 8, women who served time for person-related offenses have employment rates about 7 to 10 percentage points above their expected levels during the first two quarters after the quarter that they exit from prison. Over the longer term, these women's employment rates average about 3 percentage points above expected levels. These effects, especially the longer term effects are similar for women committed to prison for drug related offenses. For both of these groups time served also is associated with higher employment rates.

By contrast, we find that the post-prison employment rates of women serving time for property-related crimes are at their expected levels after their first full quarter out of prison. ${ }^{28}$ Over the longer-term, these women's employment rates are about 3 percentage points below their expected levels, though this difference is not statistically significant at conventional levels of statistical significance. These results indicate that employment effects of prison likely vary significantly among individuals and are consistent with the

\footnotetext{
${ }^{27}$ We do not report separate estimates for women serving time for sex-related offenses or for other offenses because their numbers in the female prison population are small and the resulting estimates are very imprecise.

${ }^{28}$ There is some evidence of this result in the literature on males. It reports that adverse effects of prison on employment are largest for white-collar type crimes, which would include crimes such as passing bad checks, embezzlement, and other types of fraud, all falling into the category of property crimes (Kling, 2001). But as we observed above, among women in our sample a large share of the property-related crimes is retail theft. Also in current research we are exploring whether these results connected with lower rates of recidivism among men released on to parole after serving time for person-related crimes.
} 
idea longer periods in prison, at least within the range observed in this population are probably associated with increased and not decreased employment prospects.

\section{Conclusion}

This paper uses a unique data set constructed from two sets of administrative records to examine the relationship between prison and employment rates for former female Illinois state prison inmates. Our results are consistent with those reported by Kling (2002) in his study of males incarcerated in California federal prisons. We find that the employment prospects of women are not adversely affected by prison. To be sure in this paper, we study only the economically disadvantaged among the Illinois female prison population. But as the high match rate between prison and social or child welfare records indicates, this characterization applies to the vast majority of female inmates.

In the short-term, which we define as the first two full quarters after the quarter they are released from prison, the employment rates are about 4 percentage points above expected levels. This finding indicates that, at least in the short-term, time in prison may foster and not harm employment prospects. We present evidence that this impact arises in part because employment retention rates are consistently higher after prison. For some groups of women, those whose prison spells lasted more than six months, those with 4 or more children, and those serving time for person-related crimes, our results indicate that time in prison also is associated with increased employment rates beyond the first few quarters after leaving prison.

One lesson from our study is that time out of the workforce or diminished skills are not an indirect (opportunity) cost of incarcerating women. Indeed, taken on its face, our results suggest that the costs of incarcerating a woman are somewhat offset by the subsequent employment gains that follow her prison spell. But, these offsetting gains are very small because these women's earnings are very low when they work. Using the estimates that we report in column 2 of Table 3, we estimate that the apparent subsequent employment gains associated with prison are worth about $\$ 600$ per female inmate to society over the first five post-prison years. This (undiscounted) amount is trivial compared to the direct costs of incarcerating woman. 
The results of this paper raise several questions for future research on the consequences of incarcerating women. First, despite the positive effects on employment rates, especially for women with many children, is there any offsetting decline in their earnings when they work? These offsetting declines may result because even though prison does not hurt the chances of finding a job, the signal it sends may make better jobs inaccessible to former inmates. Second, is the observed employment gain accompanied by an offsetting reduction in the chances of being on Food Stamps or TANF/AFDC after leaving prison? Although policy makers clearly want former inmates to become selfsufficient, it also is clearly more desirable to have women dependent on the social welfare system, which is relatively inexpensive, than to have her spending an equivalent amount of time in the criminal justice system, which is very expensive. Third, what is the connection between women whose children are in the foster care system while they are in prison and their labor market prospects after prison? Is the prospect of reuniting with children after prison associated with employment gains? Fourth, how much of the decline in pre-prison employment rates results from time spent in county jail as opposed to other circumstances that affects employment rates? Is time in county jail associated with similar employment effects as time spent in prison? Fifth can any of the post prison employment effects be linked to the receipt of specific services while in prison? Or are these effects simply the result of these women being monitored by the parole system? Sixth, how much of the dynamics in post-prison employment can be explained by recidivism? Can women returning to jail or prison explain the decline in post-prison employment rates from their peaks? Finally, our analyses do not apply to about 20 percent of the female prison population that never shows up in state child or social welfare administrative data bases. We expect this group to be more employable to start with. Does prison affect their employment outcomes differently than it does for the majority of inmates? 


\section{Appendix}

The Merged IDOC and Chapin Hall Integrated Database.

To match individual records from the Illinois Department of Corrections and the Chapin Hall Integrated Database, Chapin Hall Center for Children used probabilistic record matching. This method assumes that researchers can not match individuals' records for a single shared variable (or field) in two data sets with complete confidence. So for example, even it was possible to match former inmates' social security numbers in different data sets some matches would inevitably be in error. Instead, Chapin Hall based its matches on a statistical model that estimates the probability that two records in two different databases are for the same person using matches between as many variables as possible. For this study, these variables included all known last names, first names, birthdates, race/ethnicity indicators, and last known residence. Chapin Hall did not have individual's social security number in the IDOC file. This method for matching administrative records also was used to create the data set used by Kling (2002) in his study of male criminal defendants in federal district court felony cases in California from 1983-94.

The match rate between the IDOC file and the IDB was approximately 82 percent. Match rates outside of Cook County were higher; match rates in Cook County were 78 percent. The sample we use in this study consists of 6,991 women who do not have an IDOC prison spell between 1990 and 1995, and who do have such a spell between January 1, 1995 and December 31, 2000. Consequently, we consider our sample to consist of first-inmates with social and/or child welfare histories.

The resulting matched data set contains information on use of Food Stamps (1990-2001); AFDC/TANF (1990-2001), Medicaid (1990-2001). For women with a history on any of these programs, or a child welfare record, either as a case head or part of another case, we could obtain UI-covered earnings from 1995 through June 30, 2001. We have been provided with all UI-covered employment spells during this period, including the starting quarter, the ending quarter, and the total earnings reported by all employers during the spell.

\section{Average Quarterly Earnings and Poverty}

To compute this figure we first calculate each woman's total earnings during the 26 quarters covered by our study. We then calculate the number of calendar quarters in which her employer reports positive UI-covered earnings. The wage records for Illinois do not report how many weeks an individual works during a quarter. We then divide each woman's total earnings by the number of quarters that she had positive earnings. This is our measure of earnings when working. We report the distribution of this variable for the 4,799 women in our sample that had at least one quarter of positive earnings in Table 2.

To compute the poverty measure reported in Section III of the text, we compare the average quarterly earnings of women in our sample to the U.S. Bureau of the Census's official poverty measure for 1998. The poverty thresholds vary by household size. To account for household size in our calculations we use the number of children reported by women when they entered prison. The calculation that we report in the text is meant to answer the question of when these female inmates were working what percentage of them earned enough on average to ensure that they and their children lived 
above the official poverty threshold. In the first calculation reported in the text, we ignore the potential earnings of spouses. Only 12 percent of female inmates report being married. We base the second calculation in the text on the extreme assumption that any married woman has a husband with sufficient earnings to ensure the family lives above the relevant poverty threshold. 
Table A

Average Quarterly Employment Rates for Control Group Members in The WIN Demonstration Work/Welfare and JOBS Evaluations

\begin{tabular}{|c|c|c|c|c|}
\hline \multicolumn{3}{|c|}{$\begin{array}{l}\text { Quarterly Employment Rates (in \%) } \\
\text { Evaluation }\end{array}$} & \multirow[t]{2}{*}{ Year } & \multirow[t]{2}{*}{ \# of quarters } \\
\hline Average & Min & Max & & \\
\hline \multicolumn{3}{|c|}{ San Diego EEP/EWEP Program } & 1982-83 & 6 \\
\hline 34.4 & 27.8 & 38.1 & & \\
\hline \multicolumn{3}{|c|}{ Main TOPS Program } & 1983-84 & 11 \\
\hline 40.9 & 24.7 & 49.9 & & \\
\hline \multicolumn{3}{|c|}{ Arkansas Work Program } & 1983-84 & 3 \\
\hline 11.2 & 9.6 & 12.2 & & \\
\hline \multicolumn{3}{|c|}{ West Virginia Community Work Experience } & 1983-85 & 6 \\
\hline 11.8 & 9.2 & 13.8 & & \\
\hline \multicolumn{3}{|c|}{ Illinois Work Welfare Initiative Demonstration } & 1985 & 6 \\
\hline 20.2 & 16.2 & 23.4 & & \\
\hline \multicolumn{3}{|c|}{ San Diego SWIM Program } & 1985-87 & 9 \\
\hline 26.7 & 24.7 & 29.3 & & \\
\hline \multicolumn{3}{|c|}{ California GAIN (JOBS) Program } & 1988-90 & \\
\hline \multicolumn{3}{|c|}{ In Alameda County (Oakland) } & & 13 \\
\hline 16.2 & 21.1 & & & \\
\hline \multicolumn{3}{|c|}{ Butte County } & & 14 \\
\hline \multirow{2}{*}{\multicolumn{3}{|c|}{ Los Angeles County }} & & \\
\hline & & & & 14 \\
\hline 13.0 & 17.4 & & & \\
\hline \multicolumn{3}{|c|}{ Riverside County } & & 14 \\
\hline & 25.3 & & & \\
\hline \multicolumn{3}{|c|}{ San Diego } & & 16 \\
\hline 23.2 & 28.6 & & & \\
\hline \multicolumn{3}{|c|}{ Tulare County } & & 13 \\
\hline \multirow{2}{*}{\multicolumn{3}{|c|}{$\begin{array}{cc}21.7 & 30.7 \\
\text { Florida Project Independence (JOBS) Program }\end{array}$}} & & \\
\hline & & & 1990-91 & 9 \\
\hline 36.0 & 34.6 & 39.9 & & \\
\hline
\end{tabular}

Sources: Illinois: Freidlander et. al. (November) 1987, p. 13; Arkansas: p. 13; West Virginia: Freidlander et. al., (September) 1986, p. 11; San Diego I: Goldman et. al., (February) 1986, p. xv; Maine: Auspos, Patricia, George Cave, and David Long, "Final Report on the Training Opportunities in the Private Sector Program,”(April) 1988, p. 15; San Diego II: Friedlander, Daniel and Gayle Hamilton (November) 1989, p. 12; GAIN: Riccio, James, Daniel Friedlander, and Stephen Freedman, "GAIN: Benefits, Costs, and Three Year Impacts of a Welfare to Work Program,” (September) 1994, pp. 317 - 327; Florida: Kemple, James, Daniel Friedlander, and Veronica Fellerath, : Benefits, Costs, and Two Year Impacts of Florida's JOBS Program," p. 202. 


\section{Table B}

\section{Alternative Estimates of the Impact of Prison on Women's Employment Rates}

(Full Set of Estimates for Table 3 in the Text)

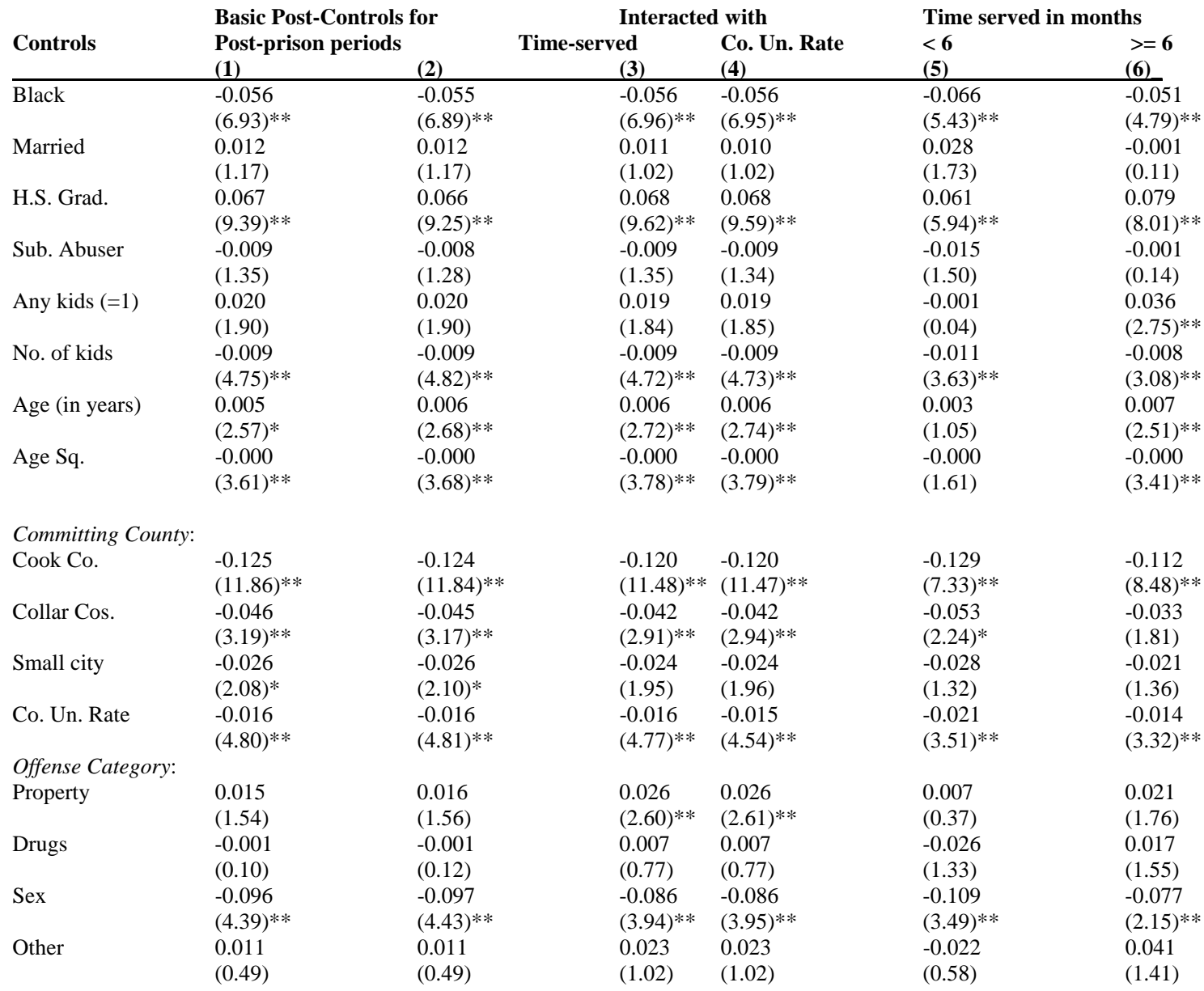

Notes: The remaining coefficients are presented in Table 3. The left-out offense category is person-related offenses; the left-out region is rural counties. Source is authors calculations based on sample of 6,991 women who entered Illinois prisons for the first time between 1995 and 2000 and who had a Food Stamp, AFDC/TANF, Medicaid record between 1990 and 2001 or a child welfare record between 1976 and 2001, as described in the text. Sample follows UI insured quarterly employment histories from 1995:I through 2001:II. Robust t-statistics are in parentheses. An * indicates estimated coefficient significant at 5\% level; and an ** indicates estimated coefficient significant at $1 \%$ level. 
Table C

Determinants of Female Offenders' Transition Rates from Employment and Non-Employment (Full Set of Estimates for Table 6 in the Text)

\begin{tabular}{|c|c|c|c|c|}
\hline Characteristic/Variable & $\begin{array}{l}\text { on from Empl } \\
\text {-employment } \\
\text { (1) }\end{array}$ & (2) & $\begin{array}{c}\text { Transition from } \\
\text { to Employment } \\
\text { (3) }\end{array}$ & $\begin{array}{l}\text { loyment } \\
\text { (4) }\end{array}$ \\
\hline Post - Prison Period & $\begin{array}{l}-0.326 \\
(.030)\end{array}$ & ---- & $\begin{array}{l}0.154 \\
(.037)\end{array}$ & ---- \\
\hline Post - Prison * Exit Quarter & --- & $\begin{array}{l}-0.485 \\
(.071)\end{array}$ & --- & $\begin{array}{l}0.579 \\
(.046)\end{array}$ \\
\hline Post - Prison $* 1^{\text {st }}$ Post-Prison Quarter & ---- & $\begin{array}{l}-0.364 \\
(.065)\end{array}$ & ---- & $\begin{array}{l}0.855 \\
(.047)\end{array}$ \\
\hline Post - Prison * 2nd Post-Prison Quarter & ---- & $\begin{array}{l}-0.301 \\
(0.062)\end{array}$ & ---- & $\begin{array}{l}0.060 \\
(.058)\end{array}$ \\
\hline Post - Prison * 3rd + Post-Prison Qtr. & ---- & $\begin{array}{l}-0.300 \\
(0.043)\end{array}$ & ---- & $\begin{array}{l}-0.112 \\
(.039)\end{array}$ \\
\hline Pre - Prison Quarter: 5 or 6 Qtrs. Before & $\begin{array}{l}0.135 \\
(.049)\end{array}$ & $\begin{array}{l}0.141 \\
(.049)\end{array}$ & $\begin{array}{l}0.031 \\
(.047)\end{array}$ & $\begin{array}{l}-0.008 \\
(.047)\end{array}$ \\
\hline Pre - Prison Quarter: 3 or 4 Qtrs. Before & $\begin{array}{l}0.302 \\
(.048)\end{array}$ & $\begin{array}{l}0.309 \\
(.048)\end{array}$ & $\begin{array}{l}-0.091 \\
(.048)\end{array}$ & $\begin{array}{l}-0.146 \\
(.047)\end{array}$ \\
\hline Pre - Prison Quarter: 1 or 2 Qtrs. Before & $\begin{array}{l}0.630 \\
(.049)\end{array}$ & $\begin{array}{l}0.638 \\
(.049)\end{array}$ & $\begin{array}{l}-0.295 \\
(.049)\end{array}$ & $\begin{array}{l}-0.358 \\
(.049)\end{array}$ \\
\hline Pre - Prison Quarter: Admission Quarter & $\begin{array}{l}1.352 \\
(.073)\end{array}$ & $\begin{array}{l}1.361 \\
(.073)\end{array}$ & $\begin{array}{l}-1.465 \\
(.093)\end{array}$ & $\begin{array}{l}-1.360 \\
(.093)\end{array}$ \\
\hline Black & $\begin{array}{l}0.259 \\
(.027)\end{array}$ & $\begin{array}{l}0.258 \\
(.027)\end{array}$ & $\begin{array}{l}-0.008 \\
(.026)\end{array}$ & $\begin{array}{l}0.001 \\
(.026)\end{array}$ \\
\hline Married & $\begin{array}{l}-0.011 \\
(.034)\end{array}$ & $\begin{array}{l}-0.011 \\
(.035)\end{array}$ & $\begin{array}{l}0.040 \\
(.033)\end{array}$ & $\begin{array}{l}0.040 \\
(.033)\end{array}$ \\
\hline H. S. Graduate & $\begin{array}{l}-0.157 \\
(.024)\end{array}$ & $\begin{array}{l}-0.155 \\
(.025)\end{array}$ & $\begin{array}{l}0.169 \\
(.023)\end{array}$ & $\begin{array}{l}0.149 \\
(.023)\end{array}$ \\
\hline From Cook County & $\begin{array}{l}-0.033 \\
(.034)\end{array}$ & $\begin{array}{l}-0.034 \\
(.034)\end{array}$ & $\begin{array}{l}-0.522 \\
(.033)\end{array}$ & $\begin{array}{l}-0.519 \\
(.033)\end{array}$ \\
\hline From other Chicago MSA Counties & $\begin{array}{l}0.186 \\
(.041)\end{array}$ & $\begin{array}{l}0.185 \\
(.041)\end{array}$ & $\begin{array}{l}-0.087 \\
(.040)\end{array}$ & $\begin{array}{l}-0.081 \\
(.040)\end{array}$ \\
\hline From counties part of another MSA & $\begin{array}{l}0.123 \\
(.038)\end{array}$ & $\begin{array}{l}0.124 \\
(.038)\end{array}$ & $\begin{array}{l}0.020 \\
(.036)\end{array}$ & $\begin{array}{l}0.014 \\
(.036)\end{array}$ \\
\hline Self-report substance abuse & $\begin{array}{l}0.087 \\
(.024)\end{array}$ & $\begin{array}{l}0.087 \\
(.024)\end{array}$ & $\begin{array}{l}0.025 \\
(.022)\end{array}$ & $\begin{array}{l}0.037 \\
(.022)\end{array}$ \\
\hline Any Children When Admitted? & $\begin{array}{l}-0.037 \\
(.037)\end{array}$ & $\begin{array}{l}-0.036 \\
(.037)\end{array}$ & $\begin{array}{l}0.082 \\
(.035)\end{array}$ & $\begin{array}{l}0.084 \\
(.035)\end{array}$ \\
\hline Number of Children at Admission & $\begin{array}{l}0.013 \\
(.008)\end{array}$ & $\begin{array}{l}0.013 \\
(.008)\end{array}$ & $\begin{array}{l}-0.024 \\
(.007)\end{array}$ & $\begin{array}{l}-0.027 \\
(.007)\end{array}$ \\
\hline Current Age & $\begin{array}{l}-0.033 \\
(.011)\end{array}$ & $\begin{array}{l}-0.034 \\
(.010)\end{array}$ & $\begin{array}{l}-0.012 \\
(.009)\end{array}$ & $\begin{array}{l}-0.007 \\
(.009)\end{array}$ \\
\hline Age squared/100 & $\begin{array}{l}0.028 \\
(.016)\end{array}$ & $\begin{array}{l}0.029 \\
(.016)\end{array}$ & $\begin{array}{l}-0.013 \\
(.013)\end{array}$ & $\begin{array}{l}-0.018 \\
(.013)\end{array}$ \\
\hline Property-related offense & $\begin{array}{l}0.015 \\
(.037)\end{array}$ & $\begin{array}{l}0.157 \\
(. .037)\end{array}$ & $\begin{array}{l}0.171 \\
(.035)\end{array}$ & $\begin{array}{l}0.175 \\
(.035)\end{array}$ \\
\hline Drug-related offense & $\begin{array}{l}0.061 \\
(.037)\end{array}$ & $\begin{array}{l}0.061 \\
(0.037)\end{array}$ & $\begin{array}{l}0.061 \\
(.035)\end{array}$ & $\begin{array}{l}0.058 \\
(.035)\end{array}$ \\
\hline Sex-related offense & $\begin{array}{l}-0.095 \\
(.113)\end{array}$ & $\begin{array}{l}-0.094 \\
(.113)\end{array}$ & $\begin{array}{l}-0.401 \\
(.098)\end{array}$ & $\begin{array}{l}-0.411 \\
(.099)\end{array}$ \\
\hline Other criminal offenses & $\begin{array}{l}0.078 \\
(.071)\end{array}$ & $\begin{array}{l}0.079 \\
(.071)\end{array}$ & $\begin{array}{l}0.174 \\
(.067)\end{array}$ & $\begin{array}{l}0.162 \\
(.067)\end{array}$ \\
\hline
\end{tabular}




$\begin{array}{lllll}\text { Current County Unemployment Rate } & 0.038 & 0.038 & -0.031 & -0.032 \\ & (.011) & (.011) & (.011) & (.011) \\ \text { Log of current duration of spell } & 0.267 & 0.262 & 1.466 & 1.435 \\ & (.043) & (.043) & (.044) & (.044) \\ \text { Square of current spell duration } & -0.237 & -0.237 & -0.584 & -0.578 \\ & (.016) & (.016) & (.014) & (.014)\end{array}$

Notes: Authors' calculations from merged IDOC - Chapin Hall IDB database. The coefficients in the table are from the logit model of transition rates described in (2) in the text. All models also include 26 quarterly dummy variables covering each quarter from 1995:I through 2001:II. 


\section{References}

Ashenfelter, Orley (1978). "Estimating the Effect of Training Programs on Earnings," Review of Economics and Statistics, 60, 47-57.

Beck, Allen and Karberg, Jennifer (2001). Prison and Jail Inmates at Midyear 2000. Bureau of Justice Statistics Bulletin. U.S. Department of Justice: Washington, D.C. NCJ 185989.

Card, David and Daniel Sullivan (1988). "Measuring the Effect of CETA Participation on Movements in and out of Employment," Econometrica, 56, 497-530.

Dalaker, Joseph (2001). Poverty in the U.S.: 2000, Current Population Reports, Consumer Income, P60-214.

Freeman, Richard B. (1992) "Crime and the Employment of Disadvantaged Youth. In Urban Labor Markets and Job Opportunity, George Peterson and Wayne Vroman, eds. Washington, DC: Urban Institute Press, 201-237.

Freeman, Richard B. (1995) “The Labor Market.” in Crime, James Q. Wilson and Joan Petersilia, eds. San Francisco, CA: Institute for Contemporary Studies, 171-191.

Freeman, Richard B. (1996). "Why Do So Many Young Men Commit Crimes and What Might We Do About It?,” Journal of Economic Perspectives, 10(1): 25-42.

Freeman, Richard (1999). "The Economics of Crime." Handbook of Labor Economics, Orley Ashenfelter and David Card, eds., Amsterdam: Elsevier.

Goerge, Robert; Van Voorhis, John and Lee, Bong Joo (1994). Illinois Longitudinal and Relational Child and Family Research Database. Social Science Computer Review, 12:3, 351-365.

Greenfeld, Lawrence, and Snell, Tracy (2000). Women Offenders. Bureau of Justice Statistics Special Report. U.S. Department of Justice, Washington, D.C. NCJ 175688

Grogger, Jeffrey. (1995) “The Effect of Arrests on the Employment and Earnings of Young Men,” Quarterly Journal of Economics,” February, 51-71.

Grogger, Jeffrey. (1998) “Market Wages and Youth Crime.” Journal of Labor Economics 16( 4, October): 756-791. 
Ham, John and Robert LaLonde, (1996). "The Effect of Sample Selection and Initial Conditions in Duration Models: Evidence from Experimental Data on Training,” Econometrica, 64(1): 175- 205, January 1996.

Heckman, James, Robert LaLonde, and Jeffery Smith (1999). “The Economics and Econometrics of Active Labor Market Policies," in The Handbook of Labor Economics, Orley Ashenfelter and David Card, eds., Amsterdam: North-Holland.

Heckman, James and Burton Singer (1984). "Econometric Duration Analysis," Journal of Econometrics, 24, 63 - 132.

Holzer, Harry and Robert LaLonde (2000). “Job Change and Job Stability Among Less Skilled Young Workers,” in Finding Jobs: Work and Welfare Reform, David Card and Rebecca Blank, eds., New York: Russell Sage Foundation.

IDES 2003: "Summary of Services," www.ides.state.il.us/individual/pubs/summary2.htm\#benefits

Kling, Jeffery, (2002). “The Effect of Prison Sentence Length on the Subsequent Employment and Earnings of Criminal Defendants,” unpublished mimeograph, Princeton University, Woodrow Wilson School, (April).

Kling, Jeffery, and Bruce Western, and David Weiman (2001). “The Labor Market Consequences of Incarceration,” Industrial Relation Section Working Paper, No. 405, Princeton University, (January).

Kornfeld, Robert and Howard Bloom (1999). "Measuring Program Impacts on Earnings and Employment: Do Unemployment Insurance Wage Records Agree with Survey Reports of Individuals,” Journal of Labor Economics, 17(1):168-197.

Kruttschnitt, Candace, and Rosemary Gartner (2003). "Women's Imprisonment," in Crime and Justice: A Review of Research, Volume 30, Michael Tonry, ed., Chicago: University of Chicago Press.

Lee, Bong Joo, Robert Goerge, and John Ditls (1999). "Outcomes for Income Maintenance Caseload after Receipt: Case Dynamics, Employment and Earnings in Illinois, 1995-1999. Chapin Hall Center for Children.

Mumola, Christopher (2000). Incarcerated Parents and Their Children. Bureau of Justice Statistics Special Report. U.S. Department of Justice: Washington, D.C. NCJ 182335.

Nagin, Daniel, and Joel Waldfogel. (1995). “The Effects of Criminality and Conviction on the Labor Market Status of Young British Offenders,” International Review of Law and Economics, 15(1):109-126. 
Needels, Karen E. (1996). "Go Directly to Jail and Do Not Collect? A Long-term Study of Recidivism, Employment, and Earnings Patterns among Prison Releases,” Journal of Research in Crime and Delinquency. 33(4): 471-496.

Rafter, N.H. (1990). Partial Justice: Women, Prisoners, and Social Control. New Brunswick N.J.: Transactions Books

Waldfogel, Joel. (1994a). "Does Conviction have a Persistent Effect on Income and Employment?," International Review of Law and Economics, 14(1): 103-119.

Waldfogel, Joel. (1994b). "The Effect of Criminal Conviction on Income and the Trust Reposed in the Workmen,” Journal of Human Resources, 29(1): 62-81. 


\section{Table 1}

\section{Means and Standard Deviations of Variables Used in Analysis of the Employment Rates of First-Time Female Illinois Prison Inmates, 1995-2000}

\begin{tabular}{|c|c|}
\hline Black & 0.660 \\
\hline Hispanic & 0.052 \\
\hline Married & 0.120 \\
\hline High school graduate & 0.330 \\
\hline From Cook Country & 0.572 \\
\hline From Collar Counties & 0.119 \\
\hline From small SNSA $^{(2)}$ & 0.134 \\
\hline Substance Abuser & 0.552 \\
\hline Children (=1) & 0.838 \\
\hline Number of children & $\begin{array}{c}2.483 \\
(1.970)^{(6)}\end{array}$ \\
\hline Age at prison entry & $\begin{array}{l}31.75 \\
(7.83)\end{array}$ \\
\hline Person-related Offense & 0.150 \\
\hline Property-related Offense & 0.332 \\
\hline Drug- related Offense & 0.473 \\
\hline Time-served ${ }^{(5)}$ & 0.775 \\
\hline County Unemployment & 4.84 \\
\hline Rate in \% ${ }^{(3)}$ & $(1.13)$ \\
\hline Employment rate ${ }^{(4)}$ & $\begin{array}{r}0.244 \\
(0.429)\end{array}$ \\
\hline Number of observations & 6,991 \\
\hline
\end{tabular}

\section{Prison Entry Cohorts 1995-1997}

0.680

0.049

0.124

0.276

0.590

0.124

0.122

0.621

0.843

2.453

(1.928)

31.30

(7.65)

0.158

0.340

0.470

0.906

4.82

(0.428)

3,695
1998-2000 Entry Cohorts

0.638

0.056

0.116

0.392

0.552

0.113

0.147

0.475

0.832

2.517

(2.015)

32.24

(7.99)

0.141

0.324

0.477

0.613

4.87

0.246

(0.431)

3,296

Notes:

(1) Individuals sentenced to state prison in one of the five counties that surround Cook County: Lake, McHenry, Kane, DuPage, and Will Counties.

(2) Counties that include a Metropolitan Statistical Area other than Chicago.

(3) County unemployment rate during the quarter that a woman exits prison. The mean unemployment rate is based on a smaller sample size because some women were still in prison at the end of the sample frame in June 2001. In the analysis reported in Tables 3, 4, and 6 through 8, the county unemployment rate is varies by quarter.

(4) Average quarterly employment rate during period from 1995:I - 2001:II

(5) Time-served refers to the actual number of days served in state prison (divided by 365) during women's first prison spell in the sample period.

(6) Standard deviations are in parentheses.

Source: Authors calculations based on matched Illinois Department of Corrections - Chapin Hall Center for Children IBD database. Sample consists of 6,991 women who were not in state prisons between 1990 and 1995 and had at least one prison spell between 1995 and 2000 and appeared in state of Illinois administrative child or social welfare databases. 


\section{Table 2}

\section{Quarterly Earnings of Female Offenders (Mean Earnings during the Quarters with Positive Earnings)}

\section{Mean (Standard Deviation)}

\section{\%-tile of Earnings} Distribution:
$1 \%$
$5 \%$
$10 \%$
$25 \%$
$50 \%$
$75 \%$
$90 \%$
$95 \%$
$99 \%$

All Prison Entry Cohorts

$\$ 1,845$

$(2,413)$

$\$ 28.65$

$\$ 87.00$

$\$ 176.12$

$\$ 491.77$

$\$ 1,174.47$

$\$ 2,322.46$

$\$ 4,173.95$

$\$ 5,713.30$

$\$ 11,444.16$
1995-1997 Prison

Entry Cohorts

$\$ 1,965$

$(2,317)$

$\$ 25.00$

$\$ 92.50$

$\$ 185.14$

$\$ 537.05$

$\$ 1,274.88$

$\$ 2,619.01$

$\$ 4,432.34$

$\$ 5,909.92$

$\$ 11,660.06$
1998-2000 Prison

Entry Cohorts

$\$ 1,709$

$(2,509)$

Number of observations

6,991

3,695

$\$ 31.72$

$\$ 78.75$

$\$ 163.87$

$\$ 466.58$

$\$ 1,064.39$

$\$ 2,052.54$

$\$ 3,788.12$

$\$ 5,338.26$

$\$ 10,932.35$

Note: Authors calculations based on sample of 6,991 former first-time female Illinois prison inmates as described in the text. The mean earnings figures are the mean of each woman's average quarterly earnings during the quarters in which she had positive UI-covered earnings. Earnings cover the period from 1995:I - 2001:II. 
Table 3

Alternative Estimates of the Impact of Prison on Women's Employment Rates (Impact on Fraction Employed During Quarter)

\begin{tabular}{|c|c|c|c|c|c|c|}
\hline Controls & \multicolumn{2}{|c|}{ Basic Post-Prison } & $\begin{array}{c}\text { Interacted w. } \\
\text { Time-served } \\
(3)\end{array}$ & $\begin{array}{c}\text { Interacted w. } \\
\text { Co. Un. Rate } \\
\text { (4) }\end{array}$ & $\begin{array}{r}\text { Time served } \\
<6 \text { months } \\
(5) \\
\end{array}$ & $\begin{array}{c}\text { Time served } \\
>=6 \text { months } \\
(6)\end{array}$ \\
\hline \multicolumn{7}{|c|}{ Relative Quarters prior to Prison: } \\
\hline $5^{\text {th }} \& 6^{\text {th }}$ pre-prison qtrs. & $\begin{array}{l}-0.006 \\
(1.10)\end{array}$ & $\begin{array}{l}-0.008 \\
(1.49)\end{array}$ & $\begin{array}{l}-0.007 \\
(1.31)\end{array}$ & $\begin{array}{l}-0.007 \\
(1.36)\end{array}$ & $\begin{array}{l}-0.007 \\
(0.97)\end{array}$ & $\begin{array}{l}-0.011 \\
(1.49)\end{array}$ \\
\hline $3^{\text {rd }} \& 4^{\text {th }}$ pre-prison qtrs. & $\begin{array}{l}-0.029 \\
(5.50)^{* *}\end{array}$ & $\begin{array}{l}-0.032 \\
(6.12)^{* *}\end{array}$ & $\begin{array}{l}-0.029 \\
(5.60)^{* *}\end{array}$ & $\begin{array}{l}-0.030 \\
(5.63)^{* *}\end{array}$ & $\begin{array}{l}-0.040 \\
(5.42)^{* *}\end{array}$ & $\begin{array}{l}-0.028 \\
(3.64)^{* *}\end{array}$ \\
\hline $1^{\text {st }} \& 2^{\text {nd }}$ pre-prison qtrs. & $\begin{array}{l}-0.062 \\
(10.89)^{* *}\end{array}$ & $\begin{array}{l}-0.065 \\
(11.65)^{* *}\end{array}$ & $\begin{array}{l}-0.062 \\
(11.07)^{* *}\end{array}$ & $\begin{array}{l}-0.062 \\
(11.05)^{* *}\end{array}$ & $\begin{array}{l}-0.061 \\
(7.75)^{* *}\end{array}$ & $\begin{array}{l}-0.070 \\
(8.64)^{* *}\end{array}$ \\
\hline Qtr. enters prison & $\begin{array}{l}-0.140 \\
(23.69) * *\end{array}$ & $\begin{array}{l}-0.143 \\
(24.85)^{* *}\end{array}$ & $\begin{array}{l}-0.139 \\
(24.00)^{* *}\end{array}$ & $\begin{array}{l}-0.140 \\
(23.85)^{* *}\end{array}$ & $\begin{array}{l}-0.111 \\
(14.07)^{* *}\end{array}$ & $\begin{array}{l}-0.162 \\
(18.62)^{* *}\end{array}$ \\
\hline In prison qtrs. & $\begin{array}{l}-0.134 \\
(17.11)^{* *}\end{array}$ & $\begin{array}{l}-0.139 \\
(18.06)^{* *}\end{array}$ & $\begin{array}{l}-0.131 \\
(16.76)^{* *}\end{array}$ & $\begin{array}{l}-0.132 \\
(16.73)^{* *}\end{array}$ & $\begin{array}{l}-0.184 \\
(13.10)^{* *}\end{array}$ & $\begin{array}{l}-0.140 \\
(14.37)^{* *}\end{array}$ \\
\hline \multicolumn{7}{|c|}{ Relative Quarters after Prison: } \\
\hline Qtr. exits prison & $\begin{array}{l}-0.011 \\
(1.64)\end{array}$ & $\begin{array}{l}-0.019 \\
(2.87) * *\end{array}$ & $\begin{array}{l}-0.014 \\
(2.10)^{*}\end{array}$ & $\begin{array}{l}-0.014 \\
(2.17)^{*}\end{array}$ & $\begin{array}{l}-0.065 \\
(7.73)^{* *}\end{array}$ & $\begin{array}{l}0.017 \\
(1.68)\end{array}$ \\
\hline Qtr is post-prison & $\begin{array}{l}0.024 \\
(2.62) * *\end{array}$ & ----- & ----- & ----- & ----- & ----- \\
\hline $1^{\text {st }}$ full post-prison qtr. & ---- & $\begin{array}{l}0.054 \\
(7.47)^{* *}\end{array}$ & $\begin{array}{l}0.014 \\
(1.74)\end{array}$ & $\begin{array}{l}0.029 \\
(1.98)^{*}\end{array}$ & $\begin{array}{l}0.005 \\
(0.57)\end{array}$ & $\begin{array}{l}0.102 \\
(9.32)^{* *}\end{array}$ \\
\hline $2^{\text {nd }}$ full post-prison qtr. & ----- & $\begin{array}{l}0.026 \\
(3.89)^{* *}\end{array}$ & $\begin{array}{l}-0.008 \\
(1.04)\end{array}$ & $\begin{array}{l}0.005 \\
(0.40)\end{array}$ & $\begin{array}{l}-0.012 \\
(1.36)\end{array}$ & $\begin{array}{l}0.068 \\
(6.56)^{* *}\end{array}$ \\
\hline $3^{\text {rd }}+$ full post-prison qtrs. & ----- & $\begin{array}{l}0.013 \\
(1.31)\end{array}$ & $\begin{array}{l}-0.021 \\
(2.05)^{*}\end{array}$ & $\begin{array}{l}-0.006 \\
(0.35)\end{array}$ & $\begin{array}{l}-0.007 \\
(0.48)\end{array}$ & $\begin{array}{l}0.038 \\
(2.67)^{* *}\end{array}$ \\
\hline $\begin{array}{l}\text { Post-Prison* } \\
\text { Time Served }\end{array}$ & ----- & ----- & $\begin{array}{l}0.063 \\
(8.76)^{* *}\end{array}$ & $\begin{array}{l}0.064 \\
(8.78)^{* *}\end{array}$ & ---- & ----- \\
\hline $\begin{array}{l}\text { Post-Prison* } \\
\text { Co. Un. Rate }\end{array}$ & ----- & ----- & ----- & $\begin{array}{l}-0.004 \\
(1.11)\end{array}$ & ----- & ----- \\
\hline Constant & $\begin{array}{l}0.337 \\
(8.52)^{* *}\end{array}$ & $\begin{array}{l}0.332 \\
(8.41)^{* *}\end{array}$ & $\begin{array}{l}0.321 \\
(8.16)^{* *}\end{array}$ & $\begin{array}{l}0.314 \\
(7.98)^{* *}\end{array}$ & $\begin{array}{l}0.432 \\
(6.55)^{* *}\end{array}$ & $\begin{array}{l}0.265 \\
(5.33)^{* *}\end{array}$ \\
\hline Person/quarter Obs. & 181,688 & 181,688 & 181,688 & 181,688 & 81,432 & 100,256 \\
\hline R-squared & 0.06 & 0.06 & 0.07 & 0.07 & 0.06 & 0.07 \\
\hline
\end{tabular}


Notes: Authors calculations based on sample of 6,991 women who entered Illinois prisons for the first time between 1995 and 2000 and who had a Food Stamp, AFDC/TANF, or Medicaid record between 1990 and 2001, or a child welfare record

as described in the text. Sample follows UI insured quarterly employment histories from 1995:I through 2001:II. All models include controls for whether a woman is black, married, or a high school graduate, her region of the state, her offense, her number of children, whether she reported a substance abuse problem when admitted to prison, her current age, the current county unemployment rate, and the log and the square of the log of the duration of the current spell as

measured in quarters. We present the estimates associated with these coefficients in Appendix Table B. All models also include 26 quarterly dummy variables covering each quarter from 1995:I through 2001:II. Post-prison quarters are quarters after the quarter that a woman exits from her first state prison spell. Robust t-statistics are in parentheses. An * indicates estimated coefficient significant at 5\% level; and an ** indicates estimated coefficient significant at $1 \%$ level. 

Table 4

Fixed Effect Estimates of the Impact of Prison on Employment Rates (Impact on Fraction Employed During Quarter)

\begin{tabular}{|c|c|c|c|c|}
\hline & Basic & $\begin{array}{l}\text { Interacted } \\
\text { Time-served }\end{array}$ & $\begin{array}{l}\text { Time served } \\
<6 \text { months }\end{array}$ & $\begin{array}{l}\text { Time served } \\
\geq 6 \text { months }\end{array}$ \\
\hline & (1) & (2) & (3) & $(4)$ \\
\hline $5^{\text {th }} \& 6^{\text {th }}$ pre-prison qtrs. & $\begin{array}{l}-0.012 \\
(2.48)^{*}\end{array}$ & $\begin{array}{l}-0.008 \\
(1.76)\end{array}$ & $\begin{array}{l}-0.006 \\
(0.87)\end{array}$ & $\begin{array}{l}-0.014 \\
(2.20)^{*}\end{array}$ \\
\hline $3^{\text {th }} \& 4^{\text {th }}$ pre-prison qtrs. & $\begin{array}{l}-0.037 \\
(7.38)^{* *}\end{array}$ & $\begin{array}{l}-0.032 \\
(6.35)^{* *}\end{array}$ & $\begin{array}{l}-0.037 \\
(5.42)^{* *}\end{array}$ & $\begin{array}{l}-0.034 \\
(4.65) * *\end{array}$ \\
\hline $1^{\text {st }} \& 2^{\text {nd }}$ pre-prison qtrs. & $\begin{array}{l}-0.070 \\
(13.44)^{* *}\end{array}$ & $\begin{array}{l}-0.063 \\
(12.14)^{* *}\end{array}$ & $\begin{array}{l}-0.057 \\
(7.89)^{* *}\end{array}$ & $\begin{array}{l}-0.076 \\
(10.10)^{* *}\end{array}$ \\
\hline Qtr. enters prison & $\begin{array}{l}-0.148 \\
(27.03)^{* *}\end{array}$ & $\begin{array}{l}-0.141 \\
(25.55)^{* *}\end{array}$ & $\begin{array}{l}-0.108 \\
(14.46)^{* *}\end{array}$ & $\begin{array}{l}-0.170 \\
(20.56)^{* *}\end{array}$ \\
\hline In Prison qtrs. & $\begin{array}{l}-0.159 \\
(22.19) * *\end{array}$ & $\begin{array}{l}-0.138 \\
(19.29) * *\end{array}$ & $\begin{array}{l}-0.211 \\
(14.48) * *\end{array}$ & $\begin{array}{l}-0.149 \\
(16.59)^{* *}\end{array}$ \\
\hline Qtr. exits prison & $\begin{array}{l}-0.019 \\
(3.13)^{* *}\end{array}$ & $\begin{array}{l}-0.012 \\
(1.92)\end{array}$ & $\begin{array}{l}-0.059 \\
(7.49)^{* *}\end{array}$ & $\begin{array}{l}0.013 \\
(1.41)\end{array}$ \\
\hline $1^{\text {st }}$ full post-prison qtr. & $\begin{array}{l}0.049 \\
(7.19)^{* *}\end{array}$ & $\begin{array}{l}0.030 \\
(4.06)^{* *}\end{array}$ & $\begin{array}{l}0.012 \\
(1.31)\end{array}$ & $\begin{array}{l}0.091 \\
(8.97)^{* *}\end{array}$ \\
\hline $2^{\text {nd }}$ full post-prison qtr. & $\begin{array}{l}0.024 \\
(3.63)^{* *}\end{array}$ & $\begin{array}{l}0.008 \\
(1.13)\end{array}$ & $\begin{array}{l}-0.005 \\
(0.53)\end{array}$ & $\begin{array}{l}0.059 \\
(5.99)^{* *}\end{array}$ \\
\hline $3^{\text {rd }}+$ full post-prison qtrs. & $\begin{array}{l}0.007 \\
(0.93)\end{array}$ & $\begin{array}{l}-0.005 \\
(0.63)\end{array}$ & $\begin{array}{l}0.006 \\
(0.56)\end{array}$ & $\begin{array}{l}0.023 \\
(1.97)^{*}\end{array}$ \\
\hline Post-prison* Time served & ----- & $\begin{array}{l}0.039 \\
(6.04)^{* *}\end{array}$ & ---- & ----- \\
\hline Unemployment Rate & $\begin{array}{l}-0.006 \\
(1.90)\end{array}$ & $\begin{array}{l}-0.006 \\
(1.90)\end{array}$ & $\begin{array}{l}-0.003 \\
(0.52)\end{array}$ & $\begin{array}{l}-0.008 \\
(2.03)^{*}\end{array}$ \\
\hline Age & $\begin{array}{l}0.030 \\
(7.10) * *\end{array}$ & $\begin{array}{l}0.027 \\
(6.31)^{* *}\end{array}$ & $\begin{array}{l}0.037 \\
(5.79)^{* *}\end{array}$ & $\begin{array}{l}0.022 \\
(3.89)^{* *}\end{array}$ \\
\hline Age squared & $\begin{array}{l}-0.000 \\
(3.26)^{* *}\end{array}$ & $\begin{array}{l}-0.000 \\
(3.10)^{* *}\end{array}$ & $\begin{array}{l}-0.000 \\
(3.57)^{* *}\end{array}$ & $\begin{array}{l}-0.000 \\
(1.25)\end{array}$ \\
\hline Constant & $\begin{array}{l}-0.452 \\
(9.34)^{* *}\end{array}$ & $\begin{array}{l}-0.367 \\
(7.52)^{* *}\end{array}$ & $\begin{array}{l}-0.578 \\
(8.06)^{* *}\end{array}$ & $\begin{array}{l}-0.280 \\
(4.20)^{* *}\end{array}$ \\
\hline Person/quarter obs. & 181,688 & 181,688 & 81,432 & 100,256 \\
\hline Number of women & 6,988 & 6,988 & 3,132 & 3,856 \\
\hline R-squared & 0.43 & 0.43 & 0.45 & 0.41 \\
\hline
\end{tabular}




\section{Table 5}

\section{Transition Rates for Quarterly Employment Spells of Female IDOC Inmates, 1995 - 2000 (Fraction Leaving Spell during Quarter)}

Quarterly Transition Rate from:

Non-employment to employment

Employment to Non-employment

\section{All periods Pre-prison Post-prison}

$\begin{array}{ccc}0.067 & 0.061 & 0.081 \\ (0.250) & (0.239) & (0.273) \\ & & \\ 0.248 & 0.296 & 0.195 \\ (0.429) & (0.457) & (0.396)\end{array}$

Notes: The table reports the fraction of non-employment and employment spells that end in any given quarter. No account is made for left-censoring or censoring when women enter prison. Given that many women's prison spells last 6 months or less and that it is possible to be placed in an Adult Transition Center in which an inmate can simultaneously be in prison and hold a UI-covered job, entering prison does not necessarily censor an employment spell. When we explicitly account for this possibility the resulting transition rates are similar to those reported above in the table. See also notes for Table 1. 


\section{Table 6}

\section{Determinants of Formerly Incarcerated Women's Transition Rates from Employment and from Non-Employment}

\begin{tabular}{|c|c|c|c|c|}
\hline \multirow[t]{2}{*}{ Characteristic/Variable } & \multicolumn{2}{|c|}{ Transition From Employment } & \multicolumn{2}{|c|}{ Transition from Non-employment } \\
\hline & (1) & $(2)$ & (3) & (4) \\
\hline Pre - Prison Quarter: 5 or 6 Qtrs. Before & $\begin{array}{l}0.135 \\
(.049)\end{array}$ & $\begin{array}{l}0.141 \\
(.049)\end{array}$ & $\begin{array}{l}0.031 \\
(.047)\end{array}$ & $\begin{array}{l}-0.008 \\
(.047)\end{array}$ \\
\hline Pre - Prison Quarter: 3 or 4 Qtrs. Before & $\begin{array}{l}0.302 \\
(.048)\end{array}$ & $\begin{array}{l}0.309 \\
(.048)\end{array}$ & $\begin{array}{l}-0.091 \\
(.048)\end{array}$ & $\begin{array}{l}-0.146 \\
(.047)\end{array}$ \\
\hline Pre - Prison Quarter: 1 or 2 Qtrs. Before & $\begin{array}{l}0.630 \\
(.049)\end{array}$ & $\begin{array}{l}0.638 \\
(.049)\end{array}$ & $\begin{array}{l}-0.295 \\
(.049)\end{array}$ & $\begin{array}{l}-0.358 \\
(.049)\end{array}$ \\
\hline Pre - Prison Quarter: Admission Quarter & $\begin{array}{l}1.352 \\
(.073)\end{array}$ & $\begin{array}{l}1.361 \\
(.073)\end{array}$ & $\begin{array}{l}-1.465 \\
(.093)\end{array}$ & $\begin{array}{l}-1.360 \\
(.093)\end{array}$ \\
\hline Post - Prison Period & $\begin{array}{l}-0.326 \\
(.030)\end{array}$ & ---- & $\begin{array}{l}0.154 \\
(.037)\end{array}$ & ---- \\
\hline Post - Prison * Exit Quarter & ---- & $\begin{array}{l}-0.485 \\
(.071)\end{array}$ & --- & $\begin{array}{l}0.579 \\
(.046)\end{array}$ \\
\hline Post - Prison * $1^{\text {st }}$ Post-Prison Quarter & ---- & $\begin{array}{l}-0.364 \\
(.065)\end{array}$ & ---- & $\begin{array}{l}0.855 \\
(.047)\end{array}$ \\
\hline Post - Prison * 2nd Post-Prison Quarter & ---- & $\begin{array}{l}-0.301 \\
(0.062)\end{array}$ & ---- & $\begin{array}{l}0.060 \\
(.058)\end{array}$ \\
\hline Post - Prison * 3rd + Post-Prison Qtr. & ---- & $\begin{array}{l}-0.300 \\
(0.043)\end{array}$ & ---- & $\begin{array}{c}-0.112 \\
(.039)\end{array}$ \\
\hline
\end{tabular}

Notes: The coefficients in the table are from the logit model of transition rates described in (2) in the text. All models include controls for whether a woman is black, married, or a high school graduate, her region of the state, her offense, her number of children, whether she reported a substance abuse problem when admitted to prison, her current age, the current county unemployment rate, and the log and the square of the $\log$ of the duration of the current spell as measured in quarters. We present the estimates associated with these coefficients in Appendix Table C. All models also include 26 quarterly dummy variables covering each quarter from 1995:I through 2001:II. See also notes for Table 1. 


\section{Table 7}

Employment Effects by Number of Children (With and Without Interactions for Time-Served)

\begin{tabular}{|c|c|c|c|c|c|c|}
\hline & NoChil & Idren & 1 to $3 c$ & hildren & 4 ormo & re Children \\
\hline & (1) & (2) & (3) & (4) & (5) & (6) \\
\hline & Basic & Interacted & Basic & Interacted & Basic & Interacted \\
\hline Pre $5^{\text {th }} \& 6^{\text {th }}$ qtrs. & -0.006 & -0.005 & -0.013 & -0.012 & 0.002 & 0.003 \\
\hline & $(0.43)$ & $(0.35)$ & $(1.90)$ & $(1.76)$ & $(0.26)$ & $(0.31)$ \\
\hline Pre $3^{\text {rd }} \& 4^{\text {th }}$ qtrs. & -0.029 & -0.027 & -0.039 & -0.036 & -0.020 & -0.017 \\
\hline & $(2.05)^{*}$ & $(1.93)$ & $(5.53)^{* *}$ & ${ }^{k}(5.11)^{* *}$ & $(2.18) *$ & $(1.90)$ \\
\hline Pre $1^{\text {st }} \& 2^{\text {nd }}$ qtrs. & -0.069 & -0.067 & -0.075 & -0.072 & -0.041 & -0.039 \\
\hline & $(4.73)^{* *}$ & ${ }^{*}(4.58)^{* *}$ & $(10.00)^{*}$ & k*(9.53)** & $(4.19)^{* *}$ & $*(3.90) * *$ \\
\hline Enter Prison qtr. & -0.167 & -0.165 & -0.159 & -0.154 & -0.096 & -0.092 \\
\hline & $(10.85)^{*}$ & $* *(10.66) * *$ & $(20.28)^{*}$ & k*(19.58)** & $(9.90)^{* *}$ & $*(9.43) * *$ \\
\hline In Prison qtrs. & -0.190 & -0.186 & -0.154 & -0.146 & -0.073 & -0.065 \\
\hline & $(10.06)^{*}$ & $k *(9.64) * *$ & $(14.80)^{*}$ & $k *(13.77) * *$ & $(5.32)^{* *}$ & $*(4.67)^{* *}$ \\
\hline Exit Prison qtr. & -0.050 & -0.047 & -0.024 & -0.018 & 0.010 & 0.014 \\
\hline & $(3.04)^{* *}$ & ${ }^{*}(2.82)^{* *}$ & $(2.73) * *$ & ${ }^{k}(2.08) *$ & $(0.89)$ & $(1.22)$ \\
\hline Post $1^{\text {st }}$ qtr. & 0.056 & 0.039 & 0.042 & -0.003 & 0.077 & 0.036 \\
\hline & $(3.00)^{* *}$ & * (1.87) & $(4.30)^{* *}$ & ${ }^{k}(0.25)$ & $(5.98)^{* *}$ & $*(2.44)^{*}$ \\
\hline Post $2^{\text {nd }}$ qtr. & 0.016 & 0.001 & 0.022 & -0.016 & 0.039 & 0.004 \\
\hline & $(0.92)$ & $(0.05)$ & $(2.42) *$ & (1.59) & $(3.27)^{* *}$ & *(0.33) \\
\hline Post $3^{\text {rd }}+$ qtrs. & 0.001 & -0.014 & -0.004 & -0.042 & 0.056 & 0.020 \\
\hline & $(0.05)$ & $(0.51)$ & $(0.33)$ & $(3.03)^{* *}$ & $(3.22)^{* *}$ & * (1.08) \\
\hline Post-prison* Time served & ---- & 0.028 & ---- & 0.070 & --- & 0.066 \\
\hline & & $(1.63)$ & & $(7.47)^{* *}$ & & $(4.56) * *$ \\
\hline Constant & 0.334 & 0.339 & 0.288 & 0.270 & 0.316 & 0.307 \\
\hline & $(3.76)^{* *}$ & ${ }^{*}(3.82) * *$ & $(5.31)^{* *}$ & ${ }^{k}(5.00) * *$ & $(3.40)^{* *}$ & * $(3.31) * *$ \\
\hline Person/Quarter Obs. & 29,484 & 29,484 & 105,482 & 105,482 & 46,722 & 46,722 \\
\hline R-squared & 0.07 & 0.08 & 0.06 & 0.07 & 0.06 & 0.06 \\
\hline
\end{tabular}


Table 8

Employment Effects by Category of Criminal Offense (With and Without Interactions for Time Served)

\section{Person Crime $\quad$ Property Crime Drug Crime}

\begin{tabular}{|c|c|c|c|c|c|c|}
\hline & $\begin{array}{l}\text { (1) } \\
\text { Basic } \\
\end{array}$ & $\begin{array}{l}\text { (2) } \\
\text { Interacted }\end{array}$ & $\begin{array}{l}\text { (3) } \\
\text { Basic } \\
\end{array}$ & $\begin{array}{l}(4) \\
\text { Interacted }\end{array}$ & $\begin{array}{l}\text { (5) } \\
\text { Basic } \\
\end{array}$ & $\begin{array}{l}\text { (6) } \\
\text { Interacted }\end{array}$ \\
\hline Pre $5^{\text {th }} \& 6^{\text {th }}$ qtrs. & $\begin{array}{l}0.002 \\
(0.14)\end{array}$ & $\begin{array}{l}0.004 \\
(0.25)\end{array}$ & $\begin{array}{l}-0.008 \\
(0.88)\end{array}$ & $\begin{array}{l}-0.008 \\
(0.85)\end{array}$ & $\begin{array}{l}-0.013 \\
(1.89)\end{array}$ & $\begin{array}{l}-0.013 \\
(1.87)\end{array}$ \\
\hline Pre $3^{\text {rd }} \& 4^{\text {th }}$ qtrs. & $\begin{array}{l}-0.027 \\
(1.82)\end{array}$ & $\begin{array}{l}-0.023 \\
(1.55)\end{array}$ & $\begin{array}{l}-0.034 \\
(3.40)^{* *}\end{array}$ & $\begin{array}{l}-0.034 \\
*(3.35)^{* *}\end{array}$ & $\begin{array}{l}-0.038 \\
(5.37)^{* *}\end{array}$ & $\begin{array}{l}-0.035 \\
*(4.98)^{* *}\end{array}$ \\
\hline Pre $1^{\text {st }} \& 2^{\text {nd }}$ qtrs. & $\begin{array}{l}-0.084 \\
(5.38)^{* *}\end{array}$ & $\begin{array}{l}-0.080 \\
*(5.04)^{* *}\end{array}$ & $\begin{array}{l}-0.072 \\
(6.74)^{* *}\end{array}$ & $\begin{array}{l}-0.071 \\
{ }^{*}(6.68) * *\end{array}$ & $\begin{array}{l}-0.061 \\
(8.17)^{* *}\end{array}$ & $\begin{array}{l}-0.058 \\
*(7.73)^{* *}\end{array}$ \\
\hline Enter Prison qtr. & $\begin{array}{l}-0.165 \\
(9.85)^{* *}\end{array}$ & $\begin{array}{l}-0.158 \\
*(9.38)^{* *}\end{array}$ & $\begin{array}{l}-0.179 \\
(16.21)^{*}\end{array}$ & $\begin{array}{l}-0.179 \\
k *(16.08) * *\end{array}$ & $\begin{array}{l}-0.117 \\
(15.36)^{*}\end{array}$ & $\begin{array}{l}-0.112 \\
* *(14.77)^{* *}\end{array}$ \\
\hline In Prison qtrs. & $\begin{array}{l}-0.221 \\
(11.43)^{*}\end{array}$ & $\begin{array}{l}-0.210 \\
* *(10.68) * *\end{array}$ & $\begin{array}{l}-0.174 \\
(12.03)^{*}\end{array}$ & $\begin{array}{l}-0.173 \\
*(11.77) * *\end{array}$ & $\begin{array}{l}-0.052 \\
(4.97)^{* *}\end{array}$ & $\begin{array}{l}-0.046 \\
*(4.30)^{* *}\end{array}$ \\
\hline Exit Prison qtr. & $\begin{array}{l}-0.036 \\
(1.97)^{*}\end{array}$ & $\begin{array}{l}-0.026 \\
(1.44)\end{array}$ & $\begin{array}{l}-0.064 \\
(5.40)^{* *}\end{array}$ & $\begin{array}{l}-0.063 \\
{ }^{*}(5.30)^{* *}\end{array}$ & $\begin{array}{l}0.019 \\
(2.06)^{*}\end{array}$ & $\begin{array}{l}0.024 \\
(2.63)^{* *}\end{array}$ \\
\hline Post $1^{\text {st }}$ qtr. & $\begin{array}{l}0.100 \\
(4.43)^{* *}\end{array}$ & $\begin{array}{r}0.030 \\
*(1.15)\end{array}$ & $\begin{array}{l}0.034 \\
(2.64)^{* *}\end{array}$ & $\begin{array}{l}0.029 \\
(1.99)^{*}\end{array}$ & $\begin{array}{l}0.056 \\
(5.68)^{* *}\end{array}$ & $\begin{array}{r}0.012 \\
*(1.04)\end{array}$ \\
\hline Post $2^{\text {nd }}$ qtr. & $\begin{array}{l}0.069 \\
(3.34)^{* *}\end{array}$ & $\begin{array}{r}0.009 \\
*(0.39)\end{array}$ & $\begin{array}{l}0.006 \\
(0.47)\end{array}$ & $\begin{array}{l}0.001 \\
(0.09)\end{array}$ & $\begin{array}{l}0.029 \\
(3.23)^{* *}\end{array}$ & $\begin{array}{l}-0.009 \\
*(0.85)\end{array}$ \\
\hline Post $3^{\text {rd }}+$ qtrs. & $\begin{array}{l}0.030 \\
(1.09)\end{array}$ & $\begin{array}{l}-0.024 \\
(0.81)\end{array}$ & $\begin{array}{l}-0.031 \\
(1.74)\end{array}$ & $\begin{array}{l}-0.036 \\
(1.91)\end{array}$ & $\begin{array}{l}0.037 \\
(2.75)^{* *}\end{array}$ & $\begin{array}{l}-0.002 \\
*(0.11)\end{array}$ \\
\hline Post-prison * Time-served & |---- & $\begin{array}{l}0.068 \\
(4.58)^{* *}\end{array}$ & ----- & $\begin{array}{l}0.010 \\
(0.68)\end{array}$ & ----- & $\begin{array}{l}0.074 \\
(6.94) * *\end{array}$ \\
\hline Constant & $\begin{array}{l}0.344 \\
(4.44)^{* *}\end{array}$ & $\begin{array}{l}0.343 \\
*(4.43)^{* *}\end{array}$ & $\begin{array}{l}0.316 \\
(4.52)^{* *}\end{array}$ & $\begin{array}{l}0.315 \\
(4.51)^{* *}\end{array}$ & $\begin{array}{l}0.372 \\
(5.51)^{* *}\end{array}$ & $\begin{aligned} & 0.367 \\
* & (5.44)^{* *}\end{aligned}$ \\
\hline $\begin{array}{l}\text { Person/Quarter Obs. } \\
\text { R-squared }\end{array}$ & $\begin{array}{l}27,248 \\
0.10\end{array}$ & $\begin{array}{l}27,248 \\
0.10\end{array}$ & $\begin{array}{l}60,398 \\
0.06 \\
\end{array}$ & $\begin{array}{l}60,398 \\
0.06 \\
\end{array}$ & $\begin{array}{l}86,034 \\
0.06 \\
\end{array}$ & $\begin{array}{l}86,034 \\
0.06 \\
\end{array}$ \\
\hline
\end{tabular}

Notes: All models also include the same independent variables that are listed in Table B. See also notes to Table 1 . The authors will provide a complete set of estimates upon request. Robust t-statistics are in parentheses. An * indicates estimated coefficient significant at 5\% level; and an ** indicates estimated coefficient significant at $1 \%$ level. 


\section{Figure 1}

Employment Rates relative to prison entry and exit (Average rate: $25.60 \%$ )

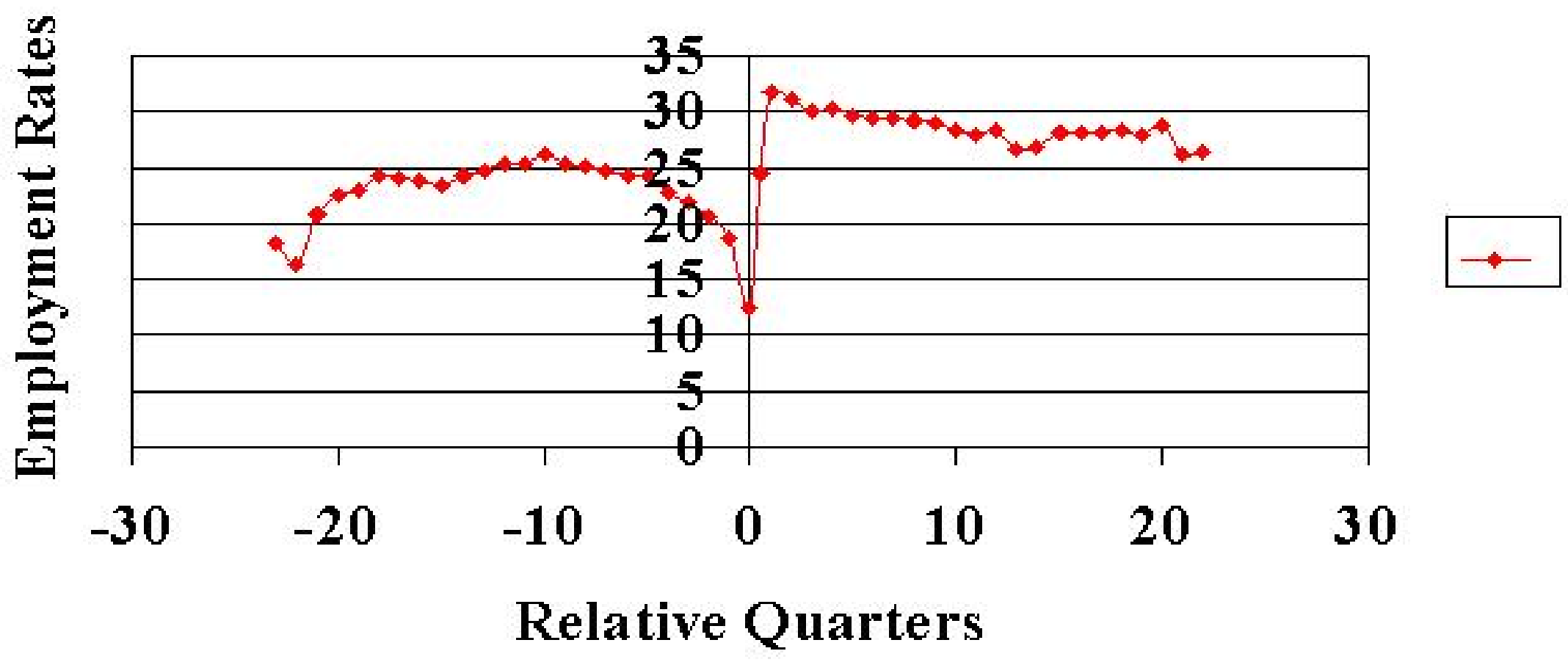




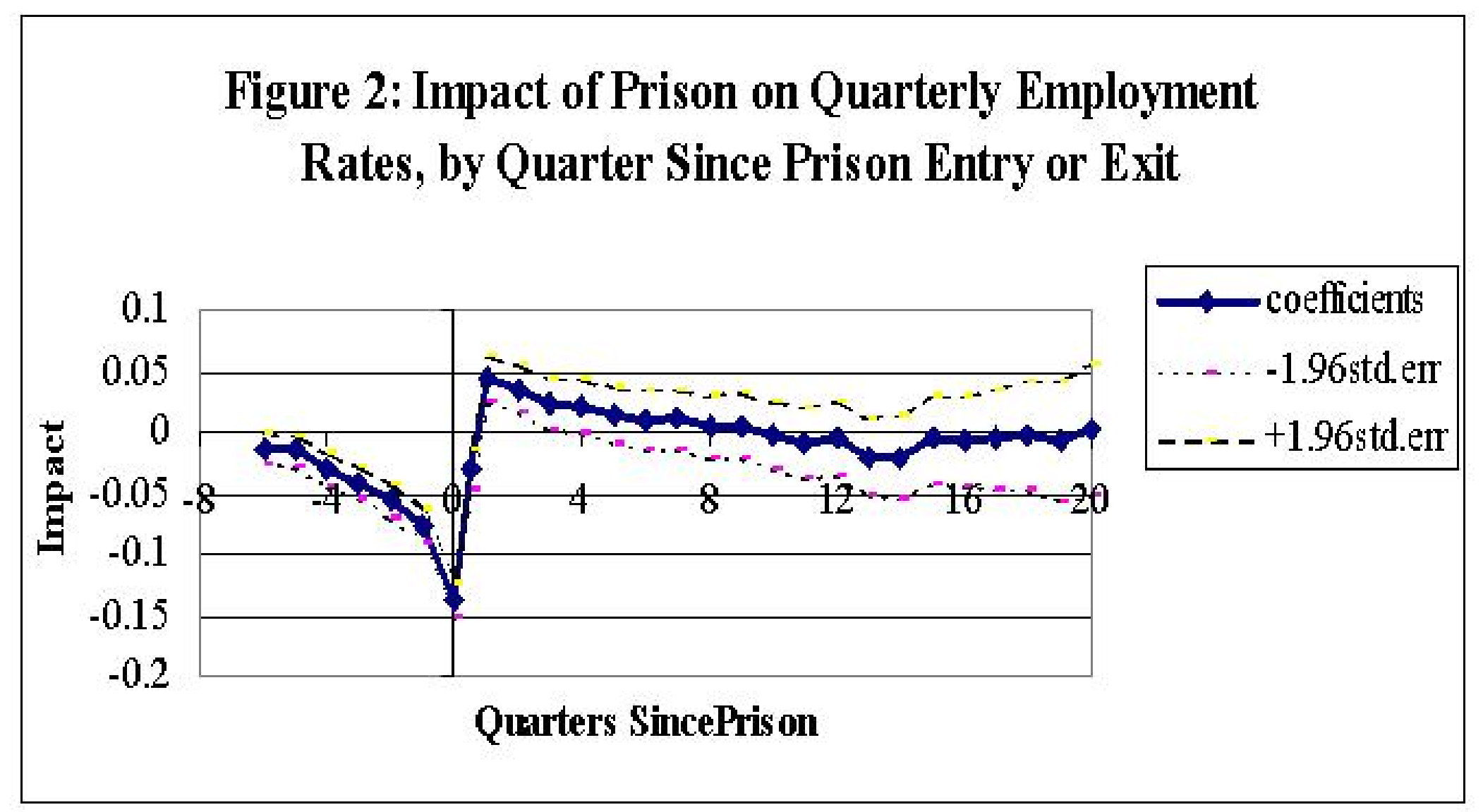

